\title{
Primary marine aerosol physical flux and chemical composition during a nutrient enrichment experiment in mesocosms in the Mediterranean Sea
}

\author{
Allison N. Schwier ${ }^{1}$, Karine Sellegri ${ }^{1}$, Sébastien Mas $^{2}$, Bruno Charrière ${ }^{3,7}$, Jorge Pey $^{4, a}$, Clémence Rose ${ }^{1}$, \\ Brice Temime-Roussel $^{4}$, Jean-Luc Jaffrezo ${ }^{5}$, David Parin ${ }^{2}$, David Picard ${ }^{1}$, Mickael Ribeiro ${ }^{1}$, Greg Roberts ${ }^{6}$, \\ Richard Sempéré ${ }^{7}$, Nicolas Marchand ${ }^{4}$, and Barbara D'Anna ${ }^{8, b}$ \\ ${ }^{1}$ Laboratoire de Météorologie Physique CNRS UMR6016, Observatoire de Physique du Globe de Clermont-Ferrand, \\ Université Blaise Pascal, 63171 Aubière, France \\ ${ }^{2}$ Centre d'écologie marine expérimentale MEDIMEER, UMS3282 OSU OREME, Université de Montpellier, \\ CNRS/IRD, Sète, France \\ ${ }^{3}$ Centre de Formation et de Recherche sur les Environnements Méditerranéens CNRS UMR5110, Université de Perpignan \\ Via Domitia, 66860 Perpignan, France \\ ${ }^{4}$ Aix Marseille Univ., CNRS, LCE, Marseille, France \\ ${ }^{5}$ Univ. Grenoble Alpes, CNRS, IRD, IGE, 38000 Grenoble, France \\ ${ }^{6}$ Centre National de Recherches Météorologiques (CNRM), Météo-France, Toulouse, France \\ ${ }^{7}$ Aix-Marseille Université, Mediterranean Institute of Oceanography (MIO), CNRS/IRD, Université de Toulon, \\ UM 110, 13288 Marseille, France \\ ${ }^{8}$ Institut de Recherches Sur la Catalyse et 1'Environnement de Lyon CNRS UMR5256, Université Claude Bernard Lyon 1, \\ 69626 Villeurbanne, France \\ a now at: Geological Survey of Spain (IGME), 50006 Zaragoza, Spain \\ b now at: Aix Marseille Univ., CNRS, LCE, Marseille, France \\ Correspondence to: Karine Sellegri (k.sellegri@opgc.cnrs.fr)
}

Received: 5 April 2017 - Discussion started: 6 June 2017

Revised: 7 September 2017 - Accepted: 1 October 2017 - Published: 8 December 2017

\begin{abstract}
While primary marine aerosol (PMA) is an important part of global aerosol total emissions, its chemical composition and physical flux as a function of the biogeochemical properties of the seawater still remain highly uncharacterized due to the multiplicity of physical, chemical and biological parameters that are involved in the emission process. Here, two nutrient-enriched mesocosms and one control mesocosm, both filled with Mediterranean seawater, were studied over a 3-week period. PMA generated from the mesocosm waters were characterized in term of chemical composition, size distribution and size-segregated cloud condensation nuclei $(\mathrm{CCN})$, as a function of the seawater chlorophyll $a$ (Chl $a$ ) concentration, pigment composition, virus and bacteria abundances. The aerosol number size distribution flux was primarily affected by the seawater temperature and did not vary significantly from one mesocosm
\end{abstract}

to the other. The aerosol number size distribution flux was primarily affected by the seawater temperature and did not vary significantly from one mesocosm to the other. Particle number and CCN aerosol fluxes increase by a factor of 2 when the temperature increases from 22 to $32^{\circ} \mathrm{C}$, for all particle submicron sizes. This effect, rarely observed in previous studies, could be specific to oligotrophic waters and/or to this temperature range. In all mesocosms (enriched and control mesocosms), we detected an enrichment of calcium $(+500 \%)$ and a deficit in chloride $(-36 \%)$ in the submicron PMA mass compared to the literature inorganic composition of the seawater. There are indications that the chloride deficit and calcium enrichment are linked to biological processes, as they are found to be stronger in the enriched mesocosms. This implies a non-linear transfer function between the seawater composition and PMA composition, with com- 
plex processes taking place at the interface during the bubble bursting. We found that the artificial phytoplankton bloom did not affect the CCN activation diameter $\left(D_{\mathrm{p}, 50 \text {, average }}=\right.$ $59.85 \pm 3.52 \mathrm{~nm}$ and $D_{\mathrm{p}, 50 \text {,average }}=93.42 \pm 5.14 \mathrm{~nm}$ for supersaturations of 0.30 and $0.15 \%$ respectively) or the organic fraction of the submicron PMA (average organic to total mass $=0.31 \pm 0.07)$ compared to the control mesocosm. Contrary to previous observations in natural bloom mesocosm experiments, the correlation between the particle organic fraction and the seawater Chl $a$ was poor, indicating that Chl $a$ is likely not a straightforward proxy for predicting, on a daily scale, PMA organic fraction in models for all types of sea and ocean waters. Instead, the organic fraction of the Aitken mode particles were more significantly linked to heterotrophic flagellates, viruses and dissolved organic carbon (DOC). We stress that different conclusions may be obtained in natural (non-enriched) or non-oligotrophic systems.

\section{Introduction}

With global submicron emissions of $\sim 10 \pm 5 \mathrm{Tg} \mathrm{yr}^{-1}$ estimated from modelling studies (Gantt and Meskhidze, 2013), primary marine aerosol (PMA), composed of both sea salt and organic material, is a large and important component of particulate matter in the atmosphere. To fully understand its importance for the climate, the physical flux and composition of the marine aerosol must be well quantified. The aerosol flux properties are highly dependent on multiple physical and chemical properties of the seawater.

The current estimates of PMA emissions can vary drastically depending on how the aerosol flux is parameterized. Size-segregated sea spray source functions used in modelling studies include physical parameters such as sea surface water temperature, salinity and wind speed (Grythe et al., 2014). Newer sea spray source functions have begun to use the wave roughness Reynolds number, which takes into account the wave development state and implicitly incorporates water temperature and salinity through a viscosity term (Norris et al., 2013; Ovadnevaite et al., 2014; Partanen et al., 2014). However, it has been known for many years that sea spray aerosol also incorporates a significant fraction of organic matter (Blanchard, 1964), which can impact aerosol physical and chemical parameters. The most common method of parameterizing the organic fraction in PMA is to correlate this organic fraction to the surface water concentration of chlorophyll $a(\mathrm{Chl} a)$. Multiple studies have observed this positive correlation through such methods as ambient aerosol measurements and chlorophyll $a$ levels detected by satellite (Ceburnis et al., unpublished data; O'Dowd et al., 2004; Rinaldi et al., 2013), by modelling the sea spray flux and using satellite chlorophyll $a$ levels (O'Dowd et al., 2008), and recently by direct PMA generation and simultaneous seawater chlorophyll $a$ measurements (Schwier et al., 2015). Ri- naldi et al. (2013) observed the strongest correlation using satellite measurements of chlorophyll $a$ concentrations with a time lag of 8 days between the particulate organic fraction and satellite chlorophyll $a$ concentration. It is important to note that in situ measurements of ambient marine aerosol include both primary and secondary aerosol formation, while marine aerosol source functions focus solely on PMA formation. Modelling studies have included marine aerosol organic fraction parameterizations to estimate aerosol emission fluxes (Albert et al., 2012; Vignati et al., 2010) and cloud condensation nuclei (CCN) concentrations (Westervelt et al., 2012). Other studies have observed correlations between the aerosol organic fraction and heterotrophic bacteria abundance (Prather et al., 2013; Schwier et al., 2015), transparent exopolymer particle (TEP) abundance (Schwier et al., 2015) or dimethyl-sulfide concentrations (Bates et al., 2012). However, Ceburnis et al. (2016) and Rinaldi et al. (2013) observed an anti-correlation between aerosol organic fraction and wind speed at $10 \mathrm{~m}$ above the sea surface at Mace Head, Ireland, that could indicate a significant contribution of secondary organic sources to the ambient aerosol organic content.

The organic fraction of PMA affects the aerosol size distribution or its log-normal mode fitting (Fuentes et al., 2010b; King et al., 2012; Schwier et al., 2015; Sellegri et al., 2006). In some modified seawater experiments, the size distributions were fit with a log-normal modal distribution and the number fraction of each mode was determined; the number concentration of the Aitken mode increased with changing organic concentrations without affecting the overall size distributions, indicating a change in the type of particles dominating the number size distribution (Collins et al., 2013). The organic fraction also has some impacts on total number concentrations (Fuentes et al., 2010b), as well as the CCN ability (Collins et al., 2013; Fuentes et al., 2011; Prather et al., 2013). Ovadnevaite et al. (2011) found a dichotomy of marine aerosol hygroscopicity and $\mathrm{CCN}$, with organics positively increasing the $\mathrm{CCN}$ activity of marine aerosols. Conversely, other works have found no noticeable effect of marine organic material on CCN activity (King et al., 2012; Moore et al., 2011).

Mesocosm experiments are used to study in situ marine aerosol production based on constrained water parameters. Prather et al. (2013) and Collins et al. (2013) performed wave channel experiments on seawater by varying bacteria, phytoplankton and chlorophyll $a$ concentrations. They observed the largest change of the aerosol activation diameter and the hygroscopicity parameter during the period of augmented heterotrophic bacteria; however, these changes did not affect the size distribution of the marine aerosol. Schwier et al. (2015) performed bubble-bursting experiments on acidified mesocosm water during pre-bloom and non-bloom (oligotrophic) conditions, and found that acidification had no strong effect on physical or chemical parameters. However, pre-bloom conditions (characterized by higher Chl $a$ con- 
centrations) enhanced the organic fraction over non-bloom conditions (low Chl $a$ concentrations) and also increased the number fraction of the Aitken mode $\left(D_{\mathrm{p}} \sim 37.5 \mathrm{~nm}\right)$ in the aerosol size distributions. However, this last work that indicates that a direct link between the primary marine aerosol organic fraction and the seawater Chl $a$ is based on the data sets issued from two different locations of the Mediterranean Sea at different seasons, and needs to be confirmed with more measurements.

Different marine environments can produce drastic seasonal differences in the aerosol flux and organic concentrations. The Mediterranean Sea is a highly oligotrophic basin (Bosc et al., 2004; MERMEX group, 2011) with seasonal blooms in the northwest of the basin (D'Ortenzio and Ribera d'Alcalà, 2009; Siokou-Frangou et al., 2010) and high UVB solar radiation in the stratified surface water during summer time (Sempéré et al., 2015). Additionally, the warm water temperatures of the Mediterranean Sea (compared to colder locations such as the North Atlantic Ocean) could also impact the PMA flux (Jaeglé et al., 2011; Long et al., 2014; Ovadnevaite et al., 2014). In this study, we performed a mesocosm experiment in the Mediterranean Sea to study an artificial bloom, different from the natural bloom period studied in the Schwier et al. (2015) study, and tracked the physical and chemical properties of primary marine aerosol that allows us to discuss the parameterization of organic material in PMA provided in earlier works.

\section{Methods}

\subsection{Measurement site and mesocosm deployment}

A mesocosm experiment was performed from 5 to 23 May 2013 in the northwestern Mediterranean Sea at the Station de Recherches Sous-marines et Océanographiques (STARESO), located in the Bay of Calvi, Corsica. The mesocosms have been described previously in the literature (Vidussi et al., 2011). Briefly, three mesocosms (1.2 m diameter, $3 \mathrm{~m}$ height) were filled with $2260 \mathrm{~L}$ of filtered $(<1000 \mu \mathrm{m})$ natural seawater and deployed in the Mediterranean Sea in the station's bay. They were closed with UV-transparent ETFE roofs, except for periods of sampling, which preserved sunlight irradiance of the mesocosm while preventing external air from entering the mesocosm headspace above the water. In order to test phytoplankton bloom conditions, one mesocosm remained unchanged as a control (A) and the other two mesocosms (B and C) were artificially enriched with nitrates and phosphates, maintaining the Redfield ratio ( $\mathrm{N}: \mathrm{P}=16$ ) (Takahashi et al., 1985). Mesocosm $\mathrm{B}$ and $\mathrm{C}$ were enriched with nutrients on 5 May to additional $3 \times\left(\mathrm{PO}_{4}^{-3}: 2.7 \mu \mathrm{M}, \mathrm{NO}_{3}^{-}: 42.3 \mu \mathrm{M}\right)$ and $1 \times\left(\mathrm{PO}_{4}^{-3}\right.$ : $\left.0.88 \mu \mathrm{M}, \mathrm{NO}_{3}^{-}: 14.03 \mu \mathrm{M}\right)$ levels, respectively; mesocosm $\mathrm{C}$ was re-enriched with nutrients to $30 \times\left(\mathrm{PO}_{4}^{3-}: 27 \mu \mathrm{M}, \mathrm{NO}_{3}^{-}\right.$:
$423 \mu \mathrm{M})$ normal levels in the evening of 12 May after sampling for the day.

In each mesocosm unit, the surface water temperature was monitored frequently (every $10 \mathrm{~min}$ ) using thermistor probes (Campbell Scientific 107), and the average mesocosm surface water temperature over the entire campaign was $17.7 \pm 0.5^{\circ} \mathrm{C}$. Water sampling was performed daily every morning (08:00 LT) by pumping $20 \mathrm{~L}$ of surface water $(50 \mathrm{~cm}$ depth) by hand from each mesocosm into polycarbonate carboys for analysis. The water was stored in large containers indoors and was covered with black bags to ensure no additional photochemical reactions took place after sampling. Non-mesocosm water (outside water) was also sampled every 3 days for a suite of biogeochemical and primary marine aerosol measurements.

For dissolved organic carbon (DOC) determination, mesocosms were directly sub-sampled into precombusted glass bottles. Sub-samples were filtrated through precombusted $\left(450{ }^{\circ} \mathrm{C}, 6 \mathrm{~h}\right) \mathrm{GF} / \mathrm{F}$ filters and transferred into $10 \mathrm{~mL}$ precombusted $\left(450^{\circ} \mathrm{C}, 6 \mathrm{~h}\right)$ glass ampoules, immediately acidified with $85 \% \mathrm{H}_{3} \mathrm{PO}_{4}$ (final $\mathrm{pH} \sim 2$ ), flame sealed, and stored at $4{ }^{\circ} \mathrm{C}$ in the dark. DOC concentration was measured by hightemperature combustion on a Shimadzu TOC 5000 analyser, as described in Sohrin and Sempéré (2005). Deep seawater reference samples (provided by D. Hansell, University of Miami) were run daily to check the accuracy of the DOC analysis. Nitrates and phosphates were measured according to Treguer et LeCorre (1975). Chl $a$ concentrations were determined using a fluorescence technique based on a methanol extraction procedure (Raimbault et al., 1988). Nitrate and chlorophyll $a$ concentration time series over the course of the campaign are shown in Fig. 1.

For phytoplankton pigment analysis, samples (0.6-1 L) were vacuum filtered $(<200 \mathrm{~mm} \mathrm{Hg})$, onto precombusted glass-fibre filters $(25 \mathrm{~mm}, 0.7 \mathrm{~mm}$ nominal pore size, $\mathrm{GF} / \mathrm{F}$, Wathman), stored in liquid nitrogen and kept at $-80^{\circ} \mathrm{C}$ until analysis. Pigments were extracted in $2.5 \mathrm{~mL}$ of $100 \%$ methanol and analysed by high-performance liquid chromatography (HPLC) as described by Wright et al. (1991). Moreover, two $1.6 \mathrm{~mL}$ aliquots for microbial plankton analyses were fixed with glutaraldehyde $(0.5 \%$ final concentration, previously filtered with a $0.02 \mu \mathrm{m}$ swinex), incubated 15 to $30 \mathrm{~min}$ at $4{ }^{\circ} \mathrm{C}$, frozen in liquid nitrogen and then stored at $-80^{\circ} \mathrm{C}$ until analysis. The two aliquots were analysed with a FacsCanto II cytometer (3-laser, 8-color (4-22), BD Biosciences) equipped with a $20 \mathrm{~mW} 488 \mathrm{~nm}$ coherent sapphire solid-state blue laser to evaluate the abundance of heterotrophic bacteria (Lebaron et al., 2001), flagellate abundance (Christaki et al., 2011) and virus (Brussaard, 2004). Finally, the determination of TEP abundance was performed by microscopic enumeration following Passow and Alldredge (1994). On each slide, 30 images were taken, at random, using a Olympus $\mathrm{AX}-70$ microscope with a $400 \times$ objective and equipped with a colour camera. For each image, all TEPs were counted manually. 

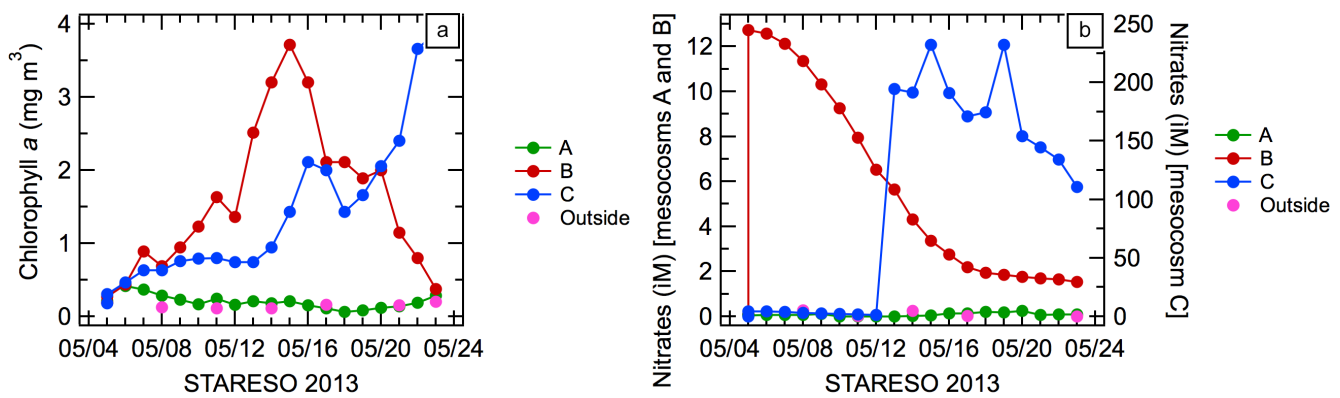

Figure 1. Temporal trends of (a) chlorophyll a concentrations measured by fluorometer and (b) nitrate concentrations measured by Technicon autoanalyser over the time course of the experiment. Panel (b) clearly shows the enrichment of mesocosm B the first day of the campaign and the enrichment of mesocosm $\mathrm{C}$ on 12 May, compared to the control mesocosm A.

\subsection{Sea spray generation and characterization}

The experimental technique has been described previously for similar types of experiments (Schwier et al., 2015). Briefly, we performed dual bubble-bursting experiments by splashing mesocosm water through plunging water jets, separated into eight jets, to generate aerosol. Two square glass tanks were filled with $3.6 \mathrm{~L}$ of seawater each (water depth of $10 \mathrm{~cm}$ ), sealed with identical stainless steel lids and flushed with particle-free air $\left(13.7 \mathrm{~L} \mathrm{~min}^{-1}\right)$ through a j-shaped tube to mimic the wind-blowing effect on bubble-bursting. Water was re-circulated via a peristaltic pump at a flow rate of $1.8 \mathrm{~L} \mathrm{~min}^{-1}$. The first $10 \mathrm{~min}$ of every experiment was used as a blank measurement to verify that the aerosol concentration was zero before starting bubbling. All the experimental conditions used (water flow rates, plunging water depth, etc.) were chosen to follow the work of Fuentes et al. (2010b). The temperature of the mesocosm water was recorded at the beginning and end of every experiment.

In between each experiment, the tanks and tubing were rinsed with ultrapure ELGA water for $10-15 \mathrm{~min}$. To ensure no experimental biases, experiments on mesocosm water (A, $B$ and C) were performed in different orders each day. In order to verify that the sampled water was not altered or affected by daily storage, we performed a bubble-bursting experiment on water sampled from one mesocosm as both the first and last experiment of the day. We observed no significant changes to any of the physical parameters of the water, verifying that the time necessary to perform all the different experiments did not affect the experimental outcome.

Two tanks were used simultaneously to perform experiments throughout the course of the campaign. The aerosol flow from one tank was passed through a diffusion drier and was sampled by a 3-stage impactor (Dekati) at $10 \mathrm{~L} \mathrm{~min}^{-1}$ for $\sim 1 \mathrm{~h}$, measuring $\mathrm{PM}_{10}, \mathrm{PM}_{2.5}$ and $\mathrm{PM}_{1}$. Quartz impactor filters also measured the whole $\mathrm{PM}_{1}$ fraction $\left(D_{\mathrm{p}}<\right.$ $1000 \mathrm{~nm})$. The quartz fibre filters were immediately stored in a refrigerator after sampling and were later extracted with Milli-Q water and analysed by ion chromatography (IC) for anions $\left(\mathrm{Cl}^{-}, \mathrm{NO}_{3}^{-}, \mathrm{C}_{2} \mathrm{O}_{4}^{2-}, \mathrm{SO}_{4}^{2-}\right)$ and cations $\left(\mathrm{Na}^{+}, \mathrm{K}^{+}\right.$,
$\mathrm{NH}_{4}^{+}, \mathrm{Mg}^{2+}, \mathrm{Ca}^{2+}$ ) (Jaffrezo et al., 1998). Analyses for elemental carbon (EC) and organic carbon (OC) were also performed using the thermo-optical transmission (TOT) method on a Sunset Lab analyser (Aymoz et al., 2007) following the EUSAAR2 temperature program proposed in Cavalli et al. (2010). The aerosol flow from the other tank was passed through a diffusion drier and a soft X-ray aerosol neutralizer (TSI Model 3088) before entering a differential mobility particle analyzer (DMA). Size-selected particles were then detected using simultaneously a condensation particle counter (CPC) and a miniature continuous-flow streamwise thermalgradient $\mathrm{CCN}$ chamber $(\mathrm{CCNc})$ (Roberts and Nenes, 2005) to determine particle $\mathrm{CCN}$ activation properties. The relative humidity of the flow entering all instruments did not exceed $20 \%$.

For the CCNc-DMPS system, aerosol flow passed first through a TSI-type DMA (length $44 \mathrm{~cm}$ ) selecting particle sizes ranging from 10 to $400 \mathrm{~nm}$. The aerosol flow was then split between the CCNc and a TSI CPC model 3010. The DMA sheath flow rate was $7.5 \mathrm{~L} \mathrm{~min}^{-1}$ and the sample flow rate was $1.35 \mathrm{~L} \mathrm{~min}^{-1}$, with $1 \mathrm{~L} \mathrm{~min}^{-1}$ to the CPC and $0.35 \mathrm{~L} \mathrm{~min}^{-1}$ to the CCNc. Multiple charge effects were taken into account, as well as CPC efficiency curve and DMA transfer function in a raw data inversion procedure that followed the European recommendations (http://www.actris. $\mathrm{eu} /$ ). However, the absence of a $\mathrm{PM}_{1}$ impactor in front of the CCNc-DMPS system led to sampling large aerosol particles with multiple charges in the $200-400 \mathrm{~nm}$ size range. Thus, in the present study we use only the data from the $10-200 \mathrm{~nm}$ size range. In the $\mathrm{CCNc}$, a total aerosol flow rate of $0.1 \mathrm{~L} \mathrm{~m}^{-1}$ with a sheath-to-aerosol flow ratio of 5 was used. The $\mathrm{CCNc}$ tested two different supersaturations (SSs) by using a temperature gradient of $5^{\circ}(\mathrm{dT} 5)$ and $6^{\circ}$ (dT6) in the column. The top temperature of the column varied as the ambient temperature changed $\left(T_{\mathrm{top}}-T_{\mathrm{amb}}=2{ }^{\circ} \mathrm{C}\right)$. Calibrations were performed with atomized $\mathrm{NaCl}$ solutions at the beginning, end and throughout the campaign. The calibration curves were corrected for doubly charged particles by removing a fraction determined with the height of the plateau in calibration 
curves (Rose et al., 2008). After this, sigmoidal fits were done separately for each of the curves of activated fraction as a function of particle diameter, and the obtained activation diameters $\left(D_{\mathrm{p} 50}\right)$ were used to calculate the $\mathrm{CCNc}$ supersaturations. First, the activation diameters were corrected for shape using a 1.08 factor. Then, the corresponding $\mathrm{CCNc}$ supersaturation was calculated based on the Köhler theory (Köhler, 1936) as presented in Seinfeld and Pandis (1998):

$S c=\exp \sqrt{\frac{256 M_{\mathrm{w}} \sigma_{\mathrm{w}}}{27 R T \rho_{\mathrm{w}}}\left(\frac{\rho_{\mathrm{w}}}{M_{\mathrm{w}}}\right)^{3}\left(\frac{\rho_{\mathrm{s}} i_{\mathrm{s}}}{M_{\mathrm{s}}}\right)^{-1} D_{\mathrm{p} 50}^{-3}}$,

where $M_{\mathrm{w}}$ and $M_{\mathrm{S}}$ are the molecular weights of water $\left(0.018 \mathrm{~kg} \mathrm{~mol}^{-1}\right)$ and solute $\left(0.058 \mathrm{~kg} \mathrm{~mol}^{-1}\right), \rho_{\mathrm{w}}$ and $\rho_{\mathrm{s}}$ are the densities of water $\left(997 \mathrm{~kg} \mathrm{~m}^{-3}\right)$ and solute $\left(2165 \mathrm{~kg} \mathrm{~m}^{-3}\right), R$ is the gas constant $\left(8.314 \mathrm{~J} \mathrm{~mol}^{-1} \mathrm{~K}^{-1}\right), T$ is the temperature $(298 \mathrm{~K}), \sigma_{\mathrm{w}}$ is the surface tension of water $\left(0.072 \mathrm{~J} \mathrm{~m}^{-2}\right), D_{\mathrm{p} 50}$ is the activation diameter, and $i_{\mathrm{s}}$ is the van't Hoff factor (Young and Warren, 1992). The van't Hoff factor was estimated to be 2, following the literature recommendations (e.g. Rose et al., 2008). The temperature differences of 6 and $5^{\circ} \mathrm{C}$ were deduced to correspond to a supersaturation of 0.30 and $0.15 \%$ respectively.

\section{Results}

\subsection{Size distributions}

The submicron size distributions of the aerosol produced from the three mesocosms were very stable over the entire course of the campaign and were directly comparable to the non-modified outside water samples. The average size distributions of the three mesocosms combined and the outside water for the entire campaign were fit with three log-normal modes (Fig. 2 and Table 1). Modal diameters of $25.0 \pm 1.5$, $49.4 \pm 1.7$ and $105.4 \pm 1.4 \mathrm{~nm}$ were observed in the mesocosm samples, and similar sizes were found in the outside water samples $(24.3 \pm 0.75,48.7 \pm 0.5$ and $104.8 \pm 0.4)$. The size distributions were then normalized with respect to the maximum total number concentration and the number fractions of each log-normal mode were calculated. No significant differences were observed temporally in the control mesocosm or the enriched mesocosms, even after the second enrichment in mesocosm C (Fig. 3). The average number fractions of Modes 2 and 3 were similar for the three mesocosms $(0.41 \pm 0.03$ and $0.45 \pm 0.04$, respectively) throughout the course of the campaign, while the number fraction of Mode 1 was smaller $(0.14 \pm 0.03)$.

\subsection{Number and $\mathrm{CCN}$ concentrations}

The total particle number (condensation nuclei, $\mathrm{CN}$ ) concentration did not show different features from one mesocosm to the other over the course of the campaign (Table 2). The measured water temperatures increased throughout the course of

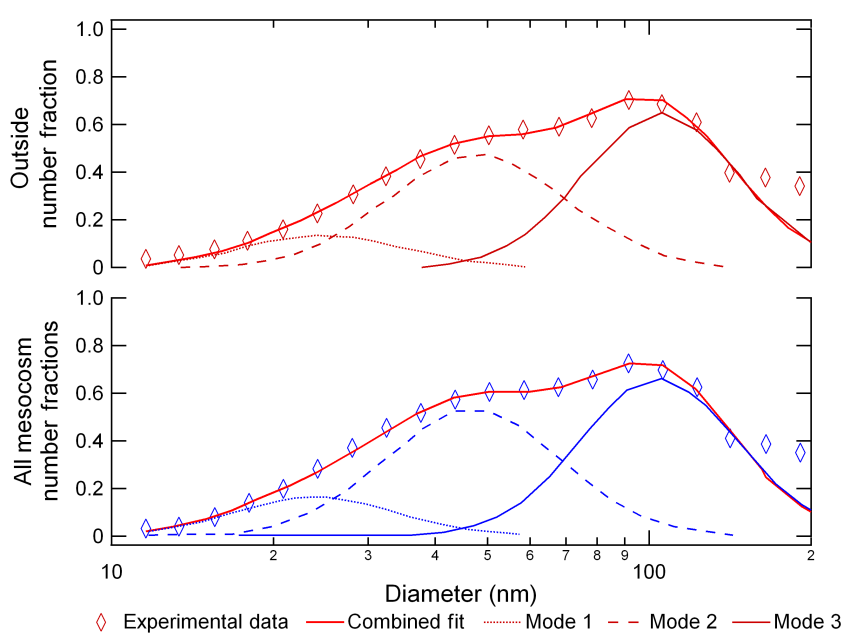

Figure 2. Average size distributions of the outside water and all mesocosms (A, B and C) at both supersaturations $(\mathrm{SS}=0.30$ and $0.15 \%)$ used in this study. The mesocosms are fit with three different log-normal modes.

a $1 \mathrm{~h}$ experiment, with an average temperature increase of $5.12 \pm 1.8^{\circ} \mathrm{Ch}^{-1}$. We use the average temperature recorded over the duration of a given experiment. Larger temperatures are systematically observed for the experiments for which the lower $\mathrm{CCN}$ supersaturations $(\mathrm{SS}=0.15 \%)$ were investigated, because these experiments were always performed after the $\mathrm{SS}=30 \%$ experiments during which the seawater temperature had increased. We converted our total number concentrations into fluxes (number of particles produced per second per water surface area with bubbles) using the air flux in the tank $\left(13.7 \mathrm{~L} \mathrm{~min}^{-1}\right)$ and the surface area covered by bubbles, following Fuentes et al. (2010a, 2011) and reported to a whitecap coverage corresponding to a $9 \mathrm{~m} \mathrm{~s}^{-1}$ wind speed (i.e. whitecap coverage of $6.89 \times 10^{-3}$ ). No correlation was found between the $\mathrm{CN}$ flux and the seawater biogeochemical characteristics. However, we see a significant positive linear correlation $\left(R^{2}=0.35, n=76, p<0.00001\right.$ at $95 \%$ significance) between the total number flux and the experimental average water temperature (Fig. 4):

CN Number Flux $\left[\mathrm{s}^{-1} \mathrm{~m}^{-2}\right]=a T\left[{ }^{\circ} \mathrm{C}\right]+b$

$\left[a=2.99 \times 10^{4} \pm 4.8 \times 10^{3} ; b=-3.43 \times 10^{5} \pm 1.21 \times 10^{5}\right]$.

Note that this relationship is only valid for the range of temperatures studied $\left(22-32^{\circ} \mathrm{C}\right)$. Mårtensson et al. (2003) also observed a positive linear parameterization for water temperature and particle number concentration in the particle diameter range 1.4-1.6 $\mu \mathrm{m}$, but an anti-correlation for smaller particles $(0.0316-0.038 \mu \mathrm{m})$. We also explicitly size segregated the flux (Fig. 5), which was observed to match previously observed experimental fluxes also shown in Fig. 5 (Clarke et al., 2006; Fuentes et al., 2010b; Mårtensson et al., 2003). 
Table 1. Log-normal modal diameter and number fraction for every mode determined from the average number size distribution. Data from Schwier et al. (2015) for the pre-bloom period tested at Bay of Villefranche (BV) and Fuentes et al. (2010) for artificial seawater are also shown.

\begin{tabular}{|c|c|c|c|c|c|c|c|c|}
\hline & \multicolumn{2}{|c|}{ Mesocosm average } & \multicolumn{2}{|c|}{ Outside water } & \multicolumn{2}{|c|}{ Schwier et al. (2015): BV } & \multicolumn{2}{|c|}{ Fuentes et al. (2010b) } \\
\hline & $D_{\mathrm{p}}(\mathrm{nm})$ & Fraction & $D_{\mathrm{p}}(\mathrm{nm})$ & Fraction & $D_{\mathrm{p}}(\mathrm{nm})$ & Fraction & $D_{\mathrm{p}}(\mathrm{nm})$ & Fraction \\
\hline Mode 1 & $25.0 \pm 1.5$ & $0.14 \pm 0.03$ & $24.3 \pm 0.75$ & $0.12 \pm 0.01$ & 20 & 0.19 & 14 & 0.38 \\
\hline Mode 2 & $49.4 \pm 1.7$ & $0.41 \pm 0.03$ & $48.7 \pm 0.5$ & $0.40 \pm 0.01$ & 37 & 0.48 & 48 & 0.32 \\
\hline Mode 3 & $105.4 \pm 1.4$ & $0.45 \pm 0.04$ & $104.8 \pm 0.4$ & $0.48 \pm 0.02$ & 92 & 0.24 & 124 & 0.17 \\
\hline Mode 4 & - & - & - & - & 260 & 0.09 & 334 & 0.13 \\
\hline
\end{tabular}

Table 2. Average number concentrations, activation diameters, kappa values $(\kappa)$ and organic fractions for each mesocosm at both supersaturations tested. Organic fractions from the filter collections $(<1000 \mathrm{~nm})$ are also shown for all three mesocosms.

\begin{tabular}{llcccc}
\hline & Mesocosm & $\begin{array}{c}\text { Number concentration } \\
\left(\mathrm{cm}^{-3}\right)\end{array}$ & $\begin{array}{c}\text { Activation diameter } \\
(\mathrm{nm})\end{array}$ & $\kappa$ & OM fraction \\
\hline $\mathrm{SS}=0.30 \%$ & A & $2590 \pm 710$ & $59.5 \pm 2.5$ & $0.74 \pm 0.09$ & $0.41 \pm 0.075$ \\
& B & $2425 \pm 710$ & $60.4 \pm 3.9$ & $0.72 \pm 0.13$ & $0.43 \pm 0.10$ \\
& C & $2580 \pm 840$ & $59.5 \pm 4.0$ & $0.75 \pm 0.13$ & $0.40 \pm 0.10$ \\
& Outside & $2300 \pm 967$ & $59.5 \pm 2.6$ & $0.74 \pm 0.095$ & $0.41 \pm 0.08$ \\
\hline SS $=0.15 \%$ & A & $2930 \pm 864$ & $93.3 \pm 3.9$ & $0.82 \pm 0.10$ & $0.35 \pm 0.08$ \\
& B & $3400 \pm 630$ & $89.9 \pm 4.5$ & $0.92 \pm 0.15$ & $0.26 \pm 0.12$ \\
& C & $3090 \pm 540$ & $97.1 \pm 4.5$ & $0.73 \pm 0.10$ & $0.42 \pm 0.08$ \\
\hline Filters & A & - & - & - & $0.38 \pm 0.05$ \\
& B & - & - & - & $0.35 \pm 0.11$ \\
& C & - & - & & $0.34 \pm 0.11$ \\
\hline
\end{tabular}

The nutrient enrichment of the mesocosms did not affect the $\mathrm{CCN}$ activity. The ratio of $\mathrm{CCN}$ to condensation nuclei at $\mathrm{SS}=0.30 \% \quad(0.15 \%)$ remains similar for all three mesocosms over time, with $\quad \mathrm{CCN} / \mathrm{CN}_{\text {average, } \mathrm{A}}=0.60 \pm 0.03 \quad(0.38 \pm 0.03)$, $\mathrm{CCN} / \mathrm{CN}_{\text {average,B }}=0.62 \pm 0.14 \quad(0.38 \pm 0.02) \quad$ and $\mathrm{CCN} / \mathrm{CN}_{\text {average, } \mathrm{C}}=0.58 \pm 0.06(0.33 \pm 0.03)$ for mesocosms $\mathrm{A}, \mathrm{B}$ and $\mathrm{C}$ respectively, indicating no statistical difference between the control and enriched mesocosms. However, because we observe a correlation between $\mathrm{CN}$ and water temperature, this also indicates that a significant correlation $\left(R^{2}=0.22, n=56, p<0.00001\right.$ at $95 \%$ significance) exists between $\mathrm{CCN}(\mathrm{SS}=0.30 \%$ ) and water temperature, shown below:

CCN Number Flux $\left[\mathrm{s}^{-1} \mathrm{~m}^{-2}\right]=a T\left[{ }^{\circ} \mathrm{C}\right]+b$

$\left[a=2.00 \times 10^{4} \pm 5.1 \times 10^{3} ; b=-2.51 \times 10^{5} \pm 1.24 \times 10^{5}\right]$

\subsection{Chemical composition, organic fraction and activation diameters}

The average inorganic chemical composition of $\mathrm{PM}_{1}$ resulting from impactor sampling is given in Table 3, as the mass fractions of individual components to the total inorganic mass concentration. The average fractions are calculated from 6 individual samples performed on 6 different sampling days per mesocosms (18 samples in total). The inorganic composition of sea spray is very similar from one mesocosm to another and is very similar to the composition of sea water (Seinfeld and Pandis, 1997; Pilson, 1998), with the exception of lower fractions of chloride (on average, $45 \pm 5 \%$ of the total inorganic mass in sea spray for all mesocosms compared to $55 \%$ in typical seawater) and higher concentrations of sodium (on average, $39 \pm 3 \%$ of the total inorganic mass in sea spray from the mesocosms compared to $30.6 \%$ in typical seawater) and calcium (on average, $8 \pm 5 \%$ of the total inorganic mass in sea spray from the mesocosms compared to $1.2 \%$ in typical seawater). As a result, the mass ratio of chloride to sodium found in the aerosol phase is on average $1.15 \pm 0.14$ (from all mesocosms), which is substantially different from the ratio of chloride to sodium reported for seawater (1.8 in Seinfeld and Pandis, 1997). The depletion of chloride relative to sodium observed in the aerosol phase is of the order of $36 \%$ compared to the seawater composition. It cannot be explained by a different relative importance of ions in the Mediterranean coastal seawater compared to literature values, as this relative abundance can be considered constant for all oceans (Dittmar, 1884). The composition of coastal Mediterranean seawater does not deviate from this universal composition for the major ions reported here (Ramzy et al., 2015). Thus, the explanation for such a 
Table 3. Mass fractions of the main inorganic components in sea spray $\left(\mathrm{PM}_{1}\right)$ to the total inorganic mass measured from impactor samples on PMA generated from six samples per mesocosm, and mass fraction of the main inorganic ions in seawater reported by ${ }^{\mathrm{a}}$ Seinfeld and Pandis (1997) and ${ }^{\mathrm{b}}$ Pilson (1998).

\begin{tabular}{lrrrrrrr}
\hline Mass fractions & $\mathrm{Cl}^{-}$ & $\mathrm{SO}_{4}^{2+}$ & $\mathrm{Na}^{+}$ & $\mathrm{K}^{+}$ & $\mathrm{Mg}^{2-}$ & $\mathrm{Ca}^{2+}$ & $\mathrm{Cl}^{-} / \mathrm{Na}^{+}$ \\
\hline Meso A & $0.47 \pm 0.06$ & $0.07 \pm 0.02$ & $0.39 \pm 0.03$ & $0.00 \pm 0.00$ & $0.02 \pm 0.00$ & $0.05 \pm 0.05$ & $1.21 \pm 0.12$ \\
Meso B & $0.43 \pm 0.06$ & $0.07 \pm 0.01$ & $0.40 \pm 0.03$ & $0.00 \pm 0.00$ & $0.02 \pm 0.00$ & $0.10 \pm 0.06$ & $1.08 \pm 0.15$ \\
Meso C & $0.45 \pm 0.02$ & $0.06 \pm 0.01$ & $0.40 \pm 0.03$ & $0.00 \pm 0.00$ & $0.02 \pm 0.00$ & $0.08 \pm 0.04$ & $1.13 \pm 0.17$ \\
Seawater $^{\mathrm{a}}$ & 0.55 & 0.08 & 0.31 & 0.01 & 0.04 & 0.01 & 1.8 \\
Seawater $^{\mathrm{b}}$ & 0.55 & 0.08 & 0.31 & 0.01 & 0.04 & 0.02 & 1.8 \\
\hline
\end{tabular}

(a)

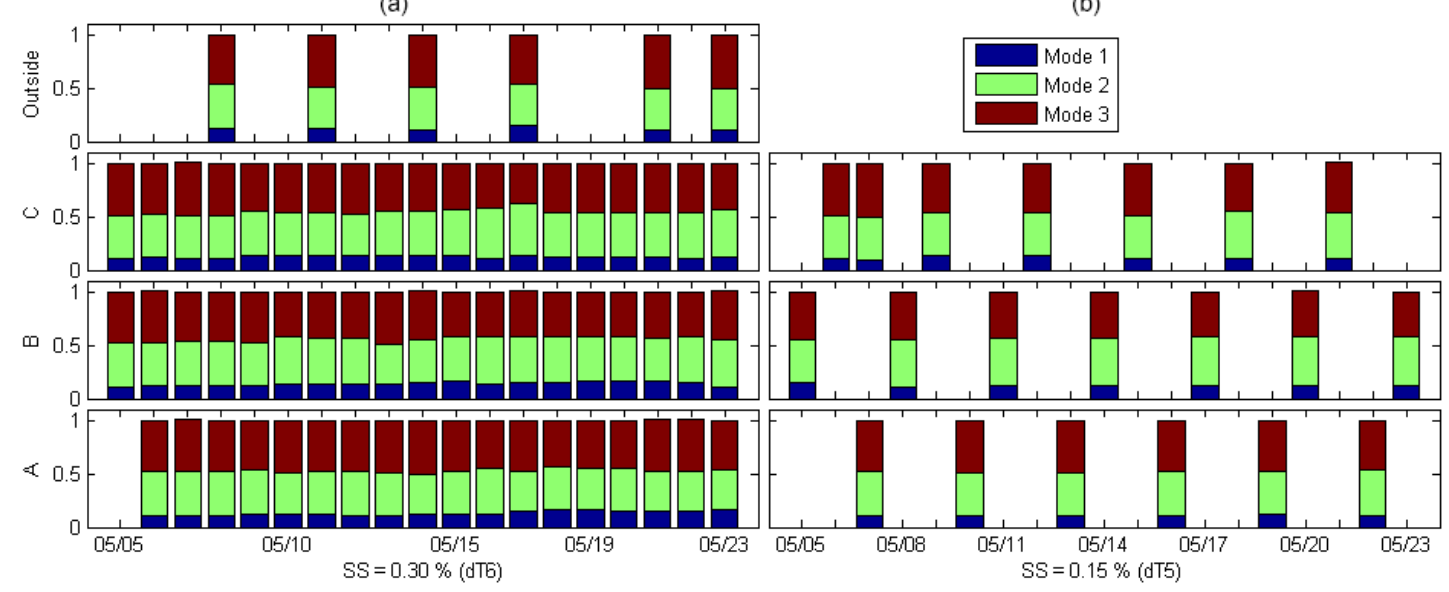

Figure 3. Number fraction of SMPS log normal modes in mesocosms A, B and C and outside water at SS $=0.30 \%$ (a) and SS $=0.15 \%$ (b).

depletion measured for primary sea salt emissions can be either that a fractionation of chloride relative to sodium happens in the course of the aerosol emission due to a different composition of the sea surface microlayer, or that there is already a chloride volatilization process that takes place during the evaporation of the film drops to aerosol residuals. In the literature, chloride-to-sodium ratios measured in the aerosol phase in ambient marine environments have usually been found to be lower than 1.2 (Bardouki et al., 2003; Koulouri et al., 2008; Pey et al., 2013), with the chloride loss usually attributed to a loss in the form of $\mathrm{HCl}$ after sodium chloride has reacted with acidic gases such as $\mathrm{HNO}_{3}$ or $\mathrm{H}_{2} \mathrm{SO}_{4}$ during the "aging" process. Our results would call into question past conclusions about sea salt aging during transport in polluted air masses.

The enrichment of $\mathrm{Ca}$ in the aerosol phase compared to the seawater composition is of the order of $500 \%$. A significant enrichment of calcium in the $\mathrm{PM}_{1}$ primary marine aerosol compared to the composition of the seawater has also been reported in earlier studies (Keene et al., 2007; Cochran et al., 2016; Salter et al., 2016), with an increased enrichment with decreasing aerosol size. The study by Salter et al. (2016) suggests that some calcium ions are clustering close to the sea surface (probably in the form of carbonate ions), and that if calcium is complexing to organic matter at the seawater surface, it is with minor amounts of organic compounds. In our study, higher chloride deficits and calcium enrichments are observed for enriched mesocosms compared to the control mesocosm, which suggests that biological processes may modulate the deficiency or enrichment of these species in the PMA compared to the seawater. A noticeable portion of free calcium in seawater is consumed by marine organisms, especially during the blooming period (Saad and Abdel-Moati, 1991). The photosynthesis process in particular causes the removal of $\mathrm{CO}_{2}$ from the seawater, causing the precipitation of $\mathrm{CaCO}_{3}$ (Saad and Hussain, 1978). This process may be enhanced at the sea surface when more light is available, explaining gradients in the calcium carbonate clusters and thus in the enrichment of calcium in aerosol particles compared to bulk seawater composition.

The organic fraction of the primary generated aerosol was addressed using two different approaches. The first one is the classical chemical analysis described above. The organic carbon fraction analysed from the 18 quartz filters collected using impactor sampling for particles $D_{\mathrm{p}}<1000 \mathrm{~nm}$ was very similar for all three mesocosms with an average value of $0.25 \pm 0.06$ of the total aerosol $\mathrm{PM}_{1}$ mass, corresponding to an organic matter $(\mathrm{OM})$ fraction of $0.31 \pm 0.07$ when using a OM-to-OC conversion ratio of 1.4 for primary organic aerosol (Turpin and Lim, 2001). Total $\mathrm{PM}_{1}$ fluxes calculated 


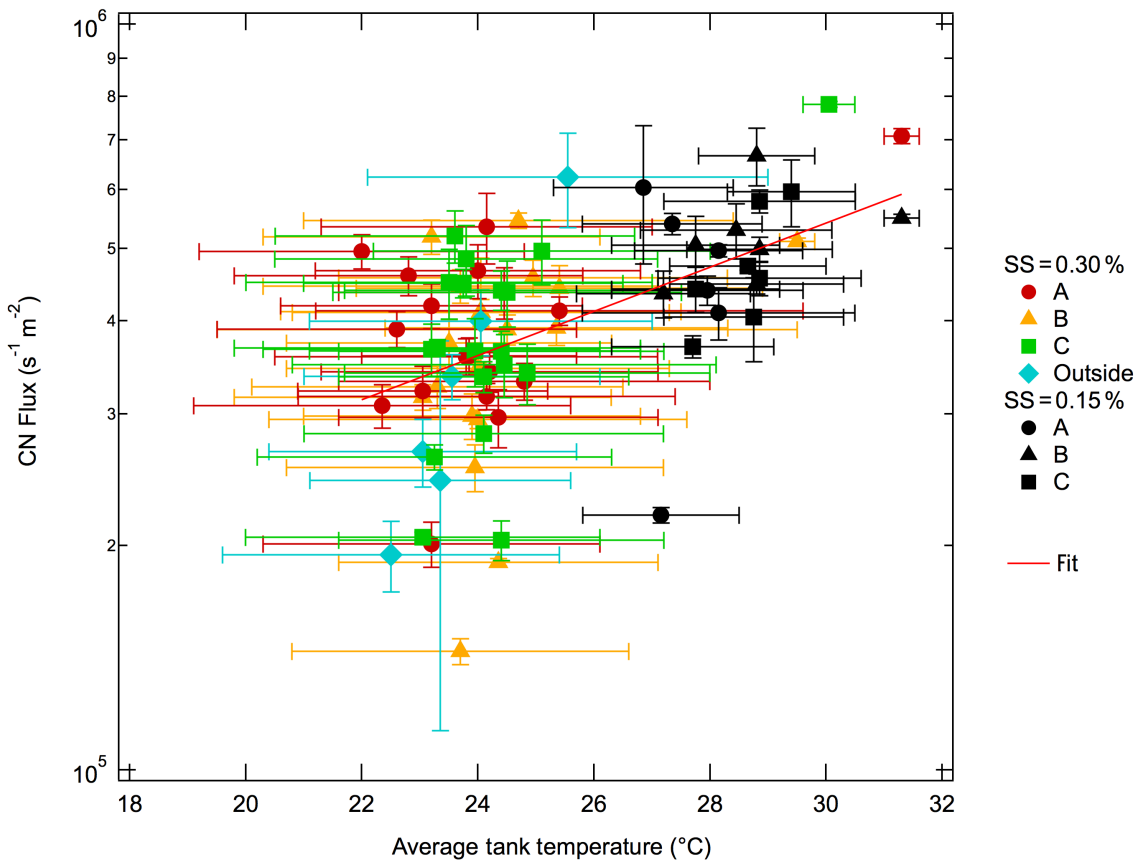

Figure 4. Particle flux calculated for a $9 \mathrm{~m} \mathrm{~s}^{-1}$ wind speed versus average tank temperature for both supersaturations tested.

from the chemical analysis of $\mathrm{OM}$ and inorganic species was $0.78,0.58$ and $0.64 \mu \mathrm{g} \mathrm{m}^{-2} \mathrm{~s}^{-1}$ for mesocosms A, B and C respectively. The chemical composition of PMA generated from mesocosm A, B and $\mathrm{C}$ are shown in Fig. 6.

The second approach is the retrieval of the organic fraction of the aerosol at its activation diameter (assuming that organics are hydrophobic) from the total aerosol hygroscopicity (in the form of the parameter kappa). Kappa ( $\kappa$ ) values were calculated from the activation diameters following Asmi et al. (2012):

$S\left(D_{\mathrm{p}}\right)=\frac{D_{\mathrm{p}}^{3}-D_{\mathrm{p}, 50}^{3}}{D_{\mathrm{p}}^{3}-D_{\mathrm{p}, 50}^{3}(1-\kappa)} \exp \left(\frac{4 \sigma_{\mathrm{w}} M_{\mathrm{w}}}{R T \rho_{\mathrm{w}} D_{\mathrm{p}}}\right)$,

where $S$ is the supersaturation, $D_{\mathrm{p}}$ is the diameter of the droplet, $D_{\mathrm{p}, 50}$ is the dry diameter, $R$ is the gas constant, $T$ is temperature, and $\sigma_{\mathrm{w}}, M_{\mathrm{w}}$, and $\rho_{\mathrm{w}}$ are the surface tension, molecular weight and density of water, respectively (Petters and Kreidenweis, 2007). Kappa values were determined by numerical iteration varying $\kappa$ until the maximum of the saturation curve was equal to the saturation used inside the CCNc. Surface tension $\rho_{\mathrm{w}}$ was approximated using the surface tension of water. The aerosol hygroscopicity parameter kappa was measured for two different temperature gradients (supersaturation) in order to investigate the organic fraction of two different particle size ranges. Table 4 shows the total number concentration, activation diameter, kappa and organic fraction individually for all 3 mesocosms and the outside water; the organic fraction calculated from filter samples is also included.
The activation diameters (Fig. 7) at $\mathrm{SS}=0.30 \%$ showed little variance between the control and enriched meso$\operatorname{cosms}\left(D_{\mathrm{p}, 50 \text {, mesocosm average }}=59.85 \pm 3.52 \mathrm{~nm}\right)$. Larger particle sizes (i.e. $90 \mathrm{~nm}$ particles measured at a lower supersaturation, $\mathrm{SS}=0.15 \%$ ) had higher activation diameters $\left(D_{\mathrm{p}, 50 \text {, mesocosm average }}=93.42 \pm 5.14 \mathrm{~nm}\right)$, again with little variance seen between the different mesocosms. The kappa value at $\mathrm{SS}=0.30 \%$ was $\kappa_{0.30 \%}=0.74 \pm 0.12$ and at $\mathrm{SS}=0.15 \%$ was $\kappa_{0.15} \%=0.82 \pm 0.14$, both very similar to the marine aerosol kappa average, $\kappa_{\text {marine }}=0.72 \pm 0.24$ (Pringle et al., 2010). Using these kappa values, the organic fraction can then be calculated using the following:

$\kappa_{\text {total }}=\varepsilon_{\text {org }} \kappa_{\text {org }}+\left(1-\varepsilon_{\text {org }}\right) \kappa_{\text {inorg }}$,

where $\kappa_{\text {org }}$ and $\kappa_{\text {inorg }}$ are the kappa of the organic and inorganic material, respectively, and $\varepsilon_{\text {org }}$ is the bulk volume fraction of organic material. The values $\kappa_{\text {inorg }}=$ 1.25 and $\kappa_{\text {org }}=0.006$ were chosen based on Collins et al. (2013) for marine aerosol. The average OM fraction for $\mathrm{SS}=0.30 \%$ (representing $60 \mathrm{~nm}$ particles) was $0.41 \pm 0.09$, and for $\mathrm{SS}=0.15 \%$ (representing $90 \mathrm{~nm}$ particles) it was $0.34 \pm 0.11$. The organic fraction of the $90 \mathrm{~nm}$ particles, representative of the accumulation mode particles, is very similar to the $\mathrm{OM}$ fraction obtained from the $\mathrm{PM}_{1}$ filter analysis reported above $(0.31 \pm 0.07)$. In comparing the organic fractions measured by filter collection and those calculated from the activation diameters, it is clear that the organic concentration decreased with increasing particle size, following the results of previous studies (O'Dowd et al., 2004; Keene et al., 2007; Schwier et al., 2015). 


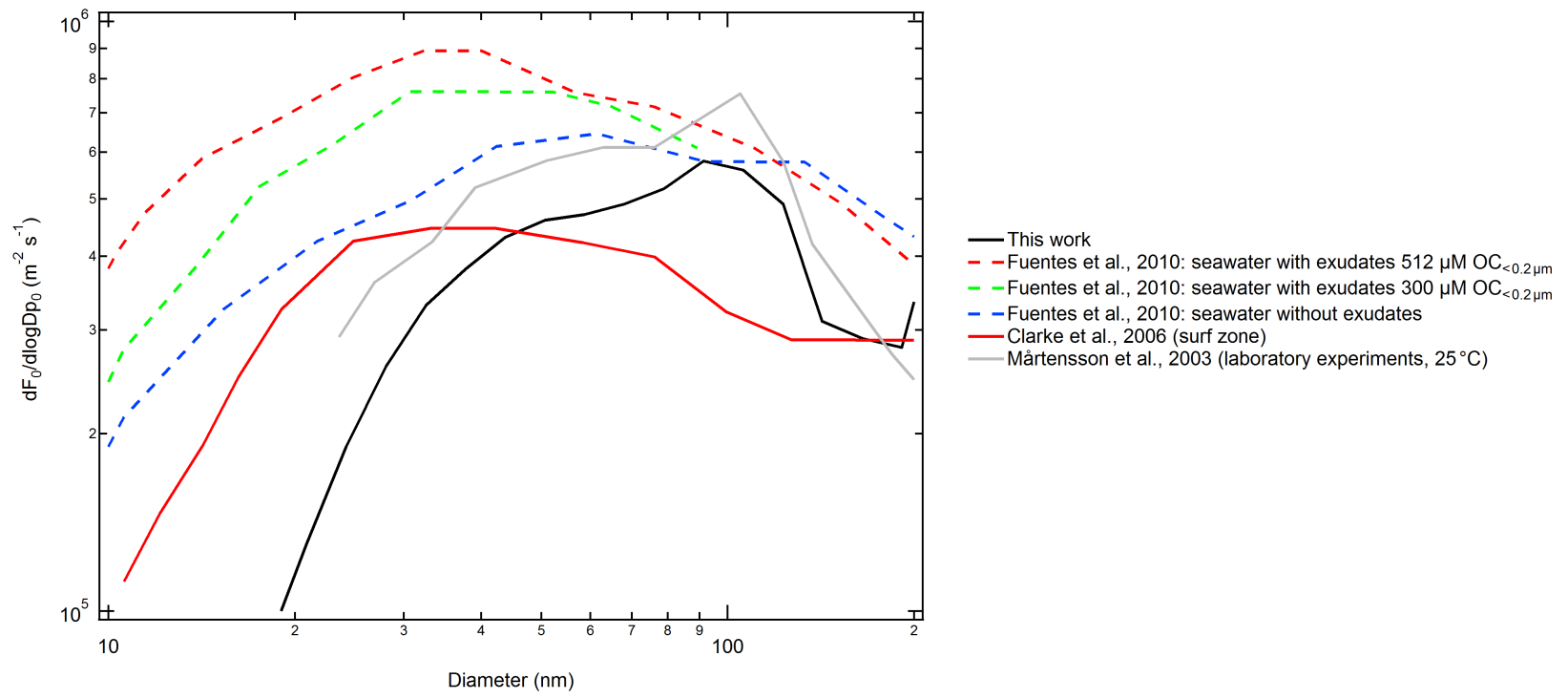

Figure 5. Comparison of size-resolved source flux measurements from previously published work and this work.
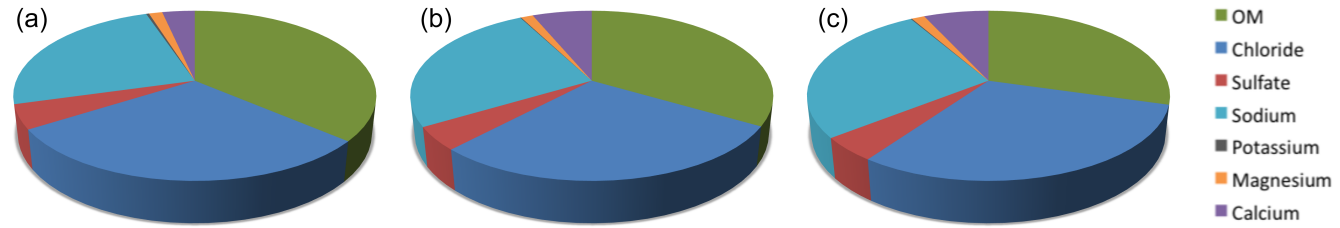

Figure 6. Average chemical composition of the $\mathrm{PM}_{1}$ PMA generated from seawater of (a) mesocosm A (control), (b) mesocosm B (enriched) and (c) mesocosm $\mathrm{C}$ (enriched).

\subsection{Correlations with biogeochemical parameters}

The different biogeochemical parameters measured during the experiment were all compared to the aerosol organic fraction, and only some of these biogeochemical parameters seem to be connected to the aerosol organic fraction. Indeed, when combining data from all mesocosms, significant correlations (at the $95 \%$ level of confidence, Table 4) were seen between the organic fraction from SS $=0.30 \%\left(D_{\mathrm{p}}=\right.$ $60 \mathrm{~nm})$ and viruses $\left(R^{2}=0.13, n=54\right)$, heterotrophic flagellates $\left(R^{2}=0.121, n=56\right)$, DOC $\left(R^{2}=0.086, n=58\right)$ and the pigment zeaxanthin representative of cyanobacteria $\left(R^{2}=0.078, n=52\right)$. No correlation was observed with chlorophyll $a$ concentrations $\left(R^{2}=0.022, n=8\right.$, Fig. 8).

However, strong linear correlations between chlorophyll $a$ concentrations and marine aerosol organic fractions have been observed in previous studies, both issued from satellite data (O'Dowd et al., 2004; Rinaldi et al., 2013) and from in situ data (Schwier et al., 2015). We used the organic fractions of larger particles from the filter collection $(<1000 \mathrm{~nm})$ instead of those calculated from the CCNc to determine if stronger correlations could be observed with the measured biogeochemical parameters. When using this organic fraction, the $R^{2}$ values of the combined mesocosm data increased, but the significance of the correlations decreased due to the lower number of points available (Table 5). The study by Schwier et al. (2015) and the present study were performed with the same experimental set-up, but still show striking opposite results, in term of relationships between the organic fraction of PMA and Chl $a$. The main difference between both studies is that, in the Schwier et al. (2015) experiments, Chl $a$ was naturally higher in one mesocosm field campaign than in the other, while in the present experiment, $\mathrm{Chl} a$ in mesocosms was artificially increased via nutrient addition. One hypothesis to explain differences is hence that artificial bloom experiments change biogeochemical equilibrium so that $\mathrm{Chl} a$ cannot be taken as a proxy for predicting the PMA organic fraction, over a 20-day period scale. In line with this observation, O'Dowd et al. (2015) did not find any relationship between $\mathrm{Chl} a$ concentration and the organic fraction of PMA for laboratory bubble-bursting experiments using water cultured in Emiliania huxleyi phytoplankton species. Prather et al. (2013) also observed no correlation with Chl $a$, while a correlation was found between organic fraction and heterotrophic flagellates. O'Dowd et al. (2015) and Rinaldi et al. (2013) found a time lag of 8 days between $\mathrm{Chl} a$ peak concentrations and the organic fraction of marine aerosols in ambient air. O'Dowd et al. (2015) suggested 
Table 4. $R^{2}$ values, number of sample points $(n)$ and $p$ values at the $95 \%$ confidence level $(p)$ of correlations between different biogeochemical parameters and the particle organic fractions calculated from the CCNc at SS $=0.30 \%$ (representing $60 \mathrm{~nm}$ particles) or from a quartz filter collection (representing $<1000 \mathrm{~nm}$ particles) from averaged data of all mesocosms. The $p$ values are given for significant correlations at the $95 \%$ confidence level and noted with an asterisk $\left(^{*}\right)$ when significant at the $90 \%$ confidence level. The $p$ significance takes into account the number of observations.

\begin{tabular}{|c|c|c|c|c|c|c|}
\hline & \multicolumn{3}{|c|}{ Organic fraction, Aitken mode } & \multicolumn{3}{|c|}{ Organic fraction, $\mathrm{PM}_{1}$} \\
\hline & $R^{2}$ & $n$ & $p$ & $R^{2}$ & $n$ & $p$ \\
\hline Total bacteria & 0.003 & 56 & & 0.016 & 19 & \\
\hline Virus & 0.13 & 54 & 0.007 & 0.166 & 17 & $0.103^{*}$ \\
\hline Heterotrophic flagellates & 0.121 & 56 & 0.009 & 0.059 & 18 & \\
\hline Cyanobacteria & 0.026 & 56 & & 0.004 & 19 & \\
\hline Pico-eukaryotes & 0.004 & 56 & & 0.016 & 19 & \\
\hline DOC & 0.086 & 58 & 0.025 & 0.05 & 19 & \\
\hline POC & 0.012 & 29 & & 0.024 & 8 & \\
\hline PON & 0.006 & 29 & & 0.013 & 8 & \\
\hline TEPs & 0.017 & 58 & & 0.015 & 19 & \\
\hline Chlorophyll $a$ (fluorometer) & 0.022 & 58 & & 0.073 & 19 & \\
\hline Chlorophyll $b$ & $8.10^{-4}$ & 54 & & 0.09 & 18 & \\
\hline Chlorophyll $c 2$ & 0.026 & 58 & & 0.077 & 19 & \\
\hline 19'-Butafucoxanthin & 0.010 & 54 & & 0.104 & 18 & \\
\hline $19^{\prime}$-Hexafucoxanthin & 0.011 & 57 & & 0.001 & 19 & \\
\hline Alloxanthin & $1.0^{-4}$ & 51 & & 0.045 & 17 & \\
\hline Diadinoxanthin & 0.028 & 57 & & 0.122 & 19 & \\
\hline Fucoxanthin & 0.013 & 57 & & 0.195 & 18 & $0.065^{*}$ \\
\hline Lutein & 0.121 & 29 & & 0.095 & 8 & \\
\hline Peridinin & 0.002 & 34 & & 0.055 & 9 & \\
\hline Pheophorbide- $a$ & 0.089 & 11 & & 0.029 & 4 & \\
\hline Prasinoxanthin & 0.077 & 35 & & 0.333 & 11 & \\
\hline Diatoxanthin & 0.036 & 37 & & 0.41 & 12 & 0.023 \\
\hline Beta carotene & 0.008 & 47 & & 0.2 & 16 & $0.081^{*}$ \\
\hline Beta epsilon carotene & 0.029 & 38 & & 0.341 & 12 & 0.044 \\
\hline Zeaxanthin & 0.078 & 52 & 0.044 & 0.018 & 17 & \\
\hline
\end{tabular}

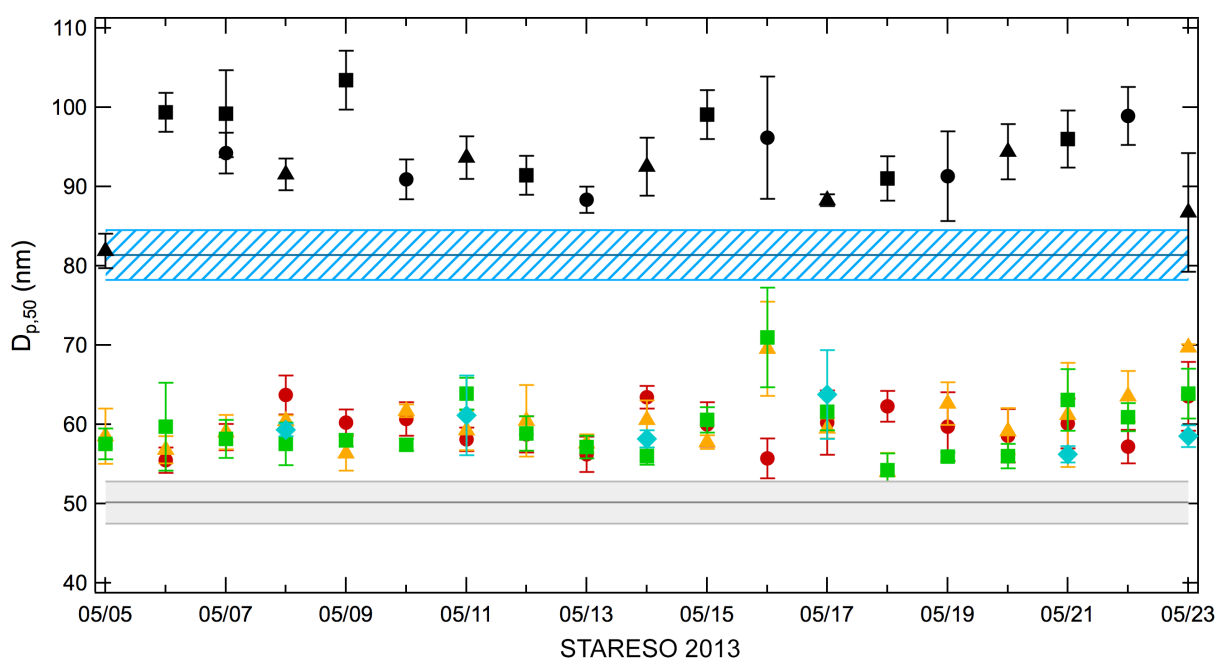

SS $=0.30 \%$

- Mesocosm A

- Mesocosm B

- Mesocosm C

- Outside water

$\square \mathrm{NaCl}$

SS $=0.15 \%$

- Mesocosm A

- Mesocosm B

- Mesocosm C

$\square \mathrm{NaCl}$

Figure 7. Activation diameters at $\mathrm{SS}=0.30 \%$ and $\mathrm{SS}=0.15 \%$. The shaded and striped areas indicate the $\mathrm{NaCl}$ activation diameters at each given supersaturation as a direct comparison to the seawater samples. 

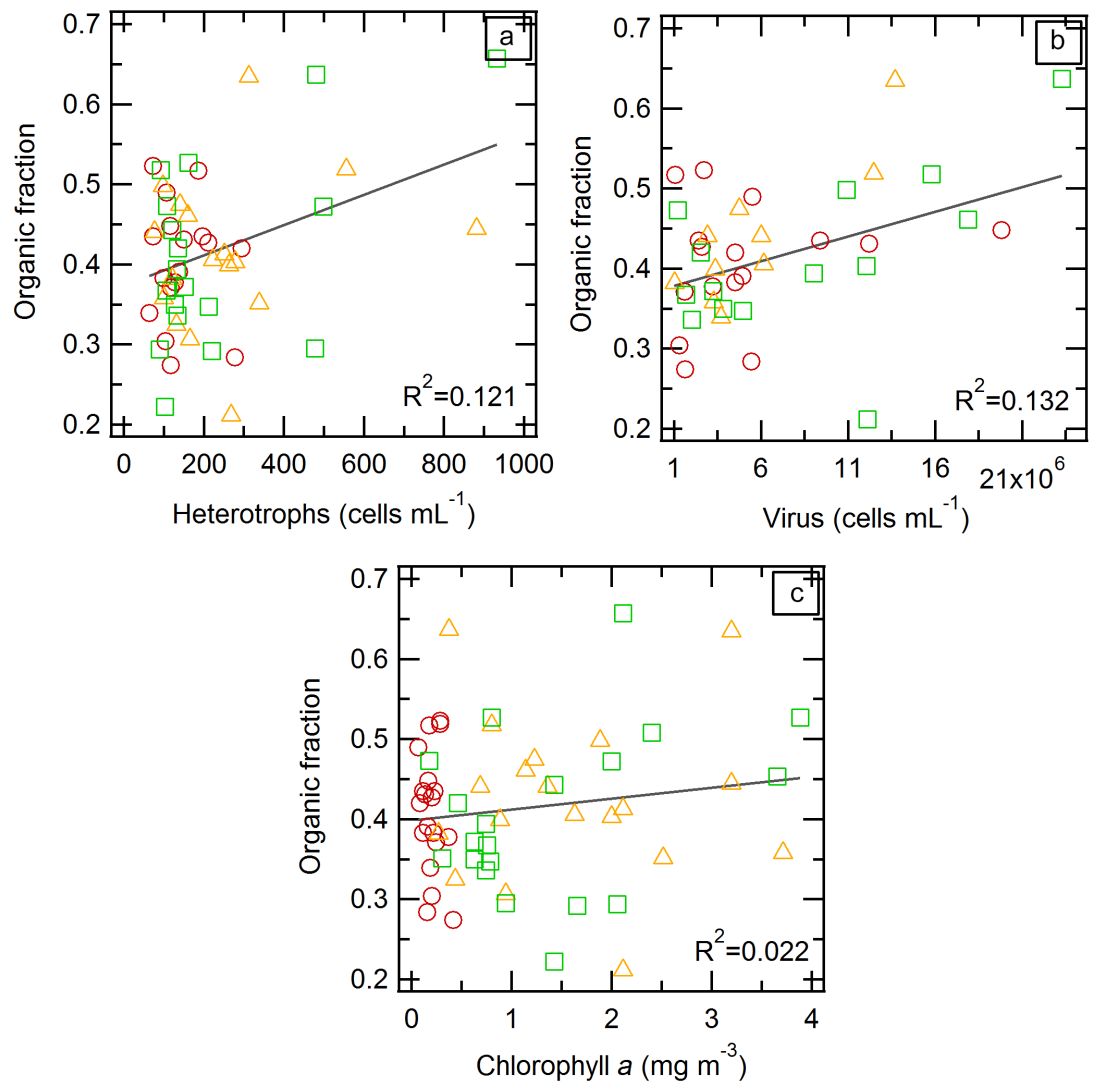

Figure 8. Correlation curves of the organic fraction from SS $=0.30 \%$ (representative for the Aitken mode particles) versus heterotrophic bacteria abundance (a), virus abundance (b) and chlorophyll $a$ concentrations (c) with $R^{2}$ values of the fit from all three mesocosms combined. Data for mesocosm A (green squares), mesocosm B (yellow triangles) and mesocosm C (red circles) are shown.

that the organic fraction of PMA is linked to the demise of the bloom due to the release of organic colloids during grazing or viral infection. The correlations found by Schwier et al. (2015) were observed over two separate seasons, which would reinforce the idea that correlations exist on a larger timescale than on a day-to-day basis. However, Schwier et al. (2015) found higher organic fractions of PMA during the pre-bloom period, and not during the period of bloom decay.

For the $\mathrm{PM}_{1}$ organic fraction, we do observe a significant correlation (only at the $90 \%$ level of confidence) with virus abundances $\left(R^{2}=0.166, n=17\right)$, while the correlation with heterotrophic flagellates, DOC and zeaxanthin is lost, but the organic fraction of these larger particles correlate with diatoxanthin (diatomes and dinoflagellates $R^{2}=0.41, n=12$ ) and carotene (cryptophytes, $R^{2}=0.341, n=12$ ) instead.

If we focus on the correlations between different biogeochemical parameters and the organic fraction for individual mesocosms, we see less significant correlations than for the combined mesocosm data, except for pigments. Using the organic fraction from $\mathrm{SS}=0.30 \%$ (representing $60 \mathrm{~nm}$ particles), we observed that the only significant correlation at the $95 \%$ confidence level in mesocosm $\mathrm{C}$ is with heterotrophic flagellates $\left(R^{2}=0.272, n=19, p=0.010\right)$ and in meso- cosm B with viruses $\left(R^{2}=0.346, n=18, p=0.005\right)$. No correlation was found in mesocosm A, which, as the control, did not experience large variability in biogeochemical properties over the course of the experiment. At the $90 \%$ confidence level, we found DOC to be correlated with the organic fraction of $60 \mathrm{~nm}$ particles in mesocosm $\mathrm{B}\left(R^{2}=0.187\right.$, $n=19, p=0.064)$. More pigments were correlated to the organic fraction of $60 \mathrm{~nm}$ particles for individual mesocosms than for the combined mesocosm data, especially for mesocosm C (chlorophyll $c 2$, fucoxanthin, diatoxanthin). More pigments were also correlated to the organic fraction of $\mathrm{PM}_{1}$ particles for individual mesocosms than for the combined mesocosm data, especially for mesocosm B (19' hexafucoxanthin, diadinoxanthin, fucoxanthin, diatoxanthin, betabeta-carotene). Different pigmented species are favoured under nutrient conditions specific to each enriched mesocosm, which may influence the organic content of aerosol particles in different size ranges. However, the complexity of the system and relatively low number of data points in each mesocosm hinder our capability of extracting clear and universal relationships with specific biological indicators. 


\section{Discussion}

Based on the consistency of the size distributions and modal diameters throughout the course of the campaign, we observed few effects on aerosol physical parameters from the mesocosm enrichments. The modal diameters observed in this work for the number distributions $(25,49,105 \mathrm{~nm})$ are similar to those observed previously using similar bubble production devices. In acidified seawater mesocosm experiments performed in the Mediterranean, Schwier et al. (2015) observed the same four log-normal modal diameters (18.5, 37.5, 91.5, $260 \mathrm{~nm}$ ) during both pre-bloom and non-bloom (oligotrophic) conditions. Fuentes et al. (2010a) observed four modes $(14,48,124,334 \mathrm{~nm})$ from similar laboratory experiments with artificial seawater. Modal diameters of 15, 45,125 and $340 \mathrm{~nm}$ were observed with artificial seawater and western African coastal seawater samples (Fuentes et al., 2010b). Wave-channel experiments with modified Pacific coastal seawater showed three modes $(\sim 90,220,1000 \mathrm{~nm})$ (Collins et al., 2013). Sellegri et al. (2006) observed three modes $(45,110,300 \mathrm{~nm})$ by using a weir to bubble synthetic seawater at $23^{\circ} \mathrm{C}$. Hultin et al. (2011) observed either two log-normal modes (site: Askö, 86, $180 \mathrm{~nm}$ ) or three lognormal modes (site: Garpen, 93, 193, $577 \mathrm{~nm}$ ) with Baltic seawater. Bubbling systems used in these various studies vary significantly in terms of the number of jets and distance between them, height of the jets to the surface of the seawater, and the presence of a blowing air jet above the surface, etc. The variability of the bubbling systems can largely explain the discrepancies between the bubble size distributions within the seawater, and hence the sea spray size distribution. Overall, however, most sea spray size distributions show an Aitken mode around $40-50 \mathrm{~nm}$ and a small accumulation mode around $100 \mathrm{~nm}$. Similar systems such as the ones used in Sellegri et al. (2006), Fuentes et al. (2010a, b) and Schwier et al. (2015) show very similar size distributions to the ones reported in the present study, with an additional ultra-fine mode around $15-25 \mathrm{~nm}$. In the present study, we did not detect the larger accumulation mode at $300 \mathrm{~nm}$, due to the smaller upper-size cut used in our DMPS system.

No change in the modal fraction was observed after either nutrient enrichment to the mesocosms. Other studies have shown an increasing number fraction of the Aitken mode with increasing heterotrophic bacteria concentration (Collins et al., 2013) and during pre-bloom periods (Schwier et al., 2015). In Schwier et al. (2015), the increase in the Aitken mode was positively correlated with viruses, heterotrophic prokaryotes, TEPs, chlorophyll $a$ and other pigments. In the present study, correlations were significant between the organic fraction of the Aitken mode and heterotrophic flagellates, viruses and with DOC, whereas it was not the case with $\mathrm{Chl} a$, for the combined data set or for the individual mesocosms. This result is different from previous observations (Schwier et al., 2015), in which a clear correlation was observed between $\mathrm{Chl} a$ and the organic fraction in the
Aitken and accumulation modes, suggesting differences in the speciation of organic material between natural and artificial blooms, which are correlated to the particle size.

The organic mass fraction calculated for $\sim 60 \mathrm{~nm}$ particles in this work $(0.41 \pm 0.075)$ in the unperturbed mesocosm A is intermediate from organic fractions observed during a natural Mediterranean pre-bloom period $(60 \mathrm{~nm}, 0.64 \pm 0.11)$ and from the same experiments during oligotrophic seawater conditions ( $47 \mathrm{~nm}, 0.24 \pm 0.14)$ (Schwier et al., 2015), indicating that only the correlation in mesocosm A between $\mathrm{Chl} a$ and $60 \mathrm{~nm}$ particles' organic fraction would be in line with previous observations. The organic fraction measured in $\mathrm{PM}_{1}$ does fall within the observed range of $30-80 \%$ organic mass fractions from sea spray aerosol studies (Collins et al., 2013; Facchini et al., 2008; Keene et al., 2007); however, marine organic mass fractions as low as $4 \%$ ( $8 \%$ volume) have also been observed (Modini et al., 2010), and the relevant biogeochemical parameters of the seawater influencing the organic fraction of sea spray are still debatable.

No clear impacts of mesocosm enrichment were observed on the total particle concentrations, which is consistent with past literature. However, the experimental temperature affected the number concentration. Hultin et al. (2011) and Zábori et al. (2012a, b) previously observed that particle number concentration decreased with increasing water temperatures in the range $10-14^{\circ} \mathrm{C}$, whereas it remained constant at higher temperatures. Salter et al. (2014) found that particle concentrations at larger sizes (dry diameter $>\sim 0.3 \mu \mathrm{m}$ ) increased slightly at temperatures between 9 and $30^{\circ} \mathrm{C}$ while smaller particle concentrations (dry diameter $>0.01 \mu \mathrm{m}$ ) remained constant. More recently, Salter et al. (2015) confirm the different behaviour of particles with diameters larger than $1 \mu \mathrm{m}$ from the ones for which diameter was smaller than $1 \mu \mathrm{m}$. They also show a rupture in the temperature dependence of submicron PMA, with a strong decrease of their number concentration with increasing temperature for temperatures below $13{ }^{\circ} \mathrm{C}$, and a very moderate decrease of number concentrations with increasing temperature for temperatures above $13^{\circ} \mathrm{C}$. These results are different from the ones observed in our study. Here we observe that within the temperature range studied $\left(22-32{ }^{\circ} \mathrm{C}\right)$, higher temperatures favoured higher particle aerosol and CCN fluxes, for all particle submicron sizes. This result could be specific to oligotrophic waters. The experiments described in Salter et al. $(2014,2015)$ were performed with synthetic seawater, and it can not be excluded that organic matter present in natural seawater influence the temperature dependence of the aerosol number emission flux. Also, while our temperatures are closer to those tested in Salter et al. (2014), their experiments were controlled at the same temperatures for up to $5 \mathrm{~h}$, while our experimental temperatures increased over the course of $1 \mathrm{~h}$. However, the number concentration throughout the course of an individual experiment most often either remained constant or increased slightly at all sizes with increasing temperature, and the shape of the size distribu- 
tion remained the same regardless of the temperature. Previous studies have incorporated water temperature effects into marine flux parameterizations. As mentioned, Mårtensson et al. (2003) observed a positive linear relationship between water temperature and 1.4-1.6 $\mu \mathrm{m}$ diameter particles, but an anti-correlation for smaller particles of $0.0316-0.038 \mu \mathrm{m}$ diameter. Jaeglé et al. (2011) empirically derived a third-order polynomial relationship between particle concentrations and water temperatures, also observing a positive correlation between the parameters. Partanen et al. (2014) and Ovadnevaite et al. (2014) used the Reynolds number to implicitly incorporate the surface water temperature in global models. Partanen et al. (2014) observed that seasonal wind speed was more important than seasonal water temperature changes in determining the sea spray aerosol flux. In a global modelling study, Ovadnevaite et al. (2014) observed that warmer water temperatures enhanced particle flux over colder water. The size-resolved flux we observed was similar to those found in most previous studies (Clarke et al., 2006; Fuentes et al., 2010b; Mårtensson et al., 2003), although the experimental apparatus tested were different (Mårtensson: sintered glass filter with synthetic seawater, Clarke: breaking wave ambient measurements, Fuentes: plunging water jet on collected seawater samples). Finally, Jaeglé et al. (2011) observed strong marine aerosol modelling underestimates in warm waters $\left(>25^{\circ} \mathrm{C}\right)$ and overestimates in colder waters $\left(<10^{\circ} \mathrm{C}\right)$ when compared to observations, showcasing the need for better marine aerosol flux parameterization, possibly adapted for different oceanic parts of the world.

\section{Conclusions}

A premeditated large enrichment was performed on two out of three mesocosms to force some physical or chemical changes in the primary marine aerosol artificially generated from the mesocosm seawater. Overall, there were little differences between properties of submicron PMA generated from the seawaters of the control and enriched mesocosms, indicating that artificial blooms did not strongly affect physical or chemical properties of primary marine aerosol in the time frame of our experiments. In the three mesocosms, we detected an enrichment of calcium and a deficit in chloride in the submicron PMA mass compared to the literature inorganic composition of the seawater. This implies a non-linear transfer function between the seawater composition and PMA composition, with complex processes taking place at the interface during the bubble-bursting process. We observed a positive linear correlation between the primary aerosol number concentration flux and the experimental water temperatures between 22 and $30^{\circ} \mathrm{C}$, which could be specific to the warm waters and organic content of the Mediterranean Sea. Correlations were observed between the organic fractions of the primary aerosol determined from the aerosol hygroscopicity $(60 \mathrm{~nm})$ and biogeochemical parame- ters such as heterotrophic flagellates and virus abundance, in agreement with recent mesocosm and wave chamber experiments. Schwier et al. (2015) observed clear differences between pre-bloom and non-bloom Mediterranean periods and found strong correlations between biogeochemical parameters and the organic fraction of $50-60 \mathrm{~nm}$ particles. Previous studies showed clear modal fraction differences and decreasing hygroscopicity with the addition of heterotrophic bacteria to natural seawater (Collins et al., 2013; Prather et al., 2013). However, we did not find any clear correlation between the Aitken mode or $\mathrm{PM}_{1}$ organic fractions of PMA and seawater Chl $a$, contrary to the findings of Schwier et al. (2015). This could indicate for this work that either (1) isolated artificial blooms in the Mediterranean do not contain the naturally complex biological-organic systems required to have a chemical or physical effect on primary marine aerosol when adjusting only marine nutrients or (2) any changes caused by artificial blooms require longer observation time periods than those used in this study or affect larger aerosol size than $1 \mu \mathrm{m}$.

Data availability. Data are available upon request.

Competing interests. The authors declare that they have no conflict of interest.

Special issue statement. This article is part of the special issue "CHemistry and AeRosols Mediterranean EXperiments (ChArMEx) (ACP/AMT inter-journal SI)". It is not associated with a conference.

Acknowledgements. This study was performed with the financial support of the ANR SAM "Sources of marine Aerosol in the Mediterranean atmosphere" (grant number: SIMI-5-6 022 04) and used the experimental facilities of the MEDIterranean center for Marine Ecosystem Experimental Research (MEDIMEER), CNRS Institute of Ecology and Environment (InEE). The authors thank the staff of STARESO (Station de Recherche Sous-Marine et Océanographique) for their hospitality and assistance in the field. Authors wish to acknowledge the support of the MISTRALCHARMEX and MISTRAL-MERMEX projects and to thank Elise Hatey and the MARBEC Cécile Roques and the MARBEC technical pole for HPLC analysis and TEP measurement. We would like to thank Christophe Salmeron and David Pecqueur from the UPMC-CNRS cytometry and imaging platform of the Banyuls Oceanographic Observatory as well as Patrick Raimbault, leader of the MIO PAPB analytical platform. We thank the two anonymous reviewers for their constructive comments that improved the paper. The authors gratefully acknowledge the MASSALYA instrumental platform (Aix Marseille Université, lce.univ-amu.fr) for the provision of analysis and measurements used in this publication. Jorge Pey acknowledges the Ramon y Cajal Research Grant (RYC-2013-14159) from the Spanish Ministry of Economy and 
Competitiveness.

Edited by: Nikolaos Mihalopoulos

Reviewed by: two anonymous referees

\section{References}

Albert, M. F. M. A., Schaap, M., Manders, A. M. M., Scannell, C., O'Dowd, C. D., and de Leeuw, G.: Uncertainties in the determination of global sub-micron marine organic matter emissions, Atmos. Environ., 57, 289-300, 2012.

Asmi, E., Freney, E., Hervo, M., Picard, D., Rose, C., Colomb, A., and Sellegri, K.: Aerosol cloud activation in summer and winter at puy-de-Dôme high altitude site in France, Atmos. Chem. Phys., 12, 11589-11607, https://doi.org/10.5194/acp-12-115892012, 2012.

Aymoz, G., Jaffrezo, J. L., Chapuis, D., Cozic, J., and Maenhaut, W.: Seasonal variation of $\mathrm{PM}_{10}$ main constituents in two valleys of the French Alps. I: EC/OC fractions, Atmos. Chem. Phys., 7, 661-675, https://doi.org/10.5194/acp-7-661-2007, 2007.

Bardouki, H., Liakakou, H., , Economou, C., Sciare, J., Smolikık, J., Zdımal, V., Eleftheriadis, K., Lazaridis, M., Dye, C., and Mihalopoulos, N., : Chemical composition of sizeresolved atmospheric aerosols in the eastern Mediterranean during summer and winter, Atmos. Environ., 37, 195-208, https://doi.org/10.1016/S1352-2310(02)00859-2, 2003.

Bates, T. S., Quinn, P. K., Frossard, A. A., Russell, L. M., Hakala, J., Petäjä, T., Kulmala, M., Covert, D. S., Cappa, C. D., Li, S.-M., Hayden, K. L., Nuaaman, I., Mclaren, R., Massoli, P., Canagaratna, M. R., Onasch, T. B., Sueper, D., Worsnop, D. R., and Keene, W. C.: Measurements of ocean derived aerosol off the coast of California, J. Geophys. Res., 117, D00V15, https://doi.org/10.1029/2012JD017588, 2012.

Blanchard, D. C.: Sea-to-Air Transport Surface Active Material, Science, 146), 396-397, 1964.

Bosc, E., Bricaud, A., and Antoine, D.: Seasonal and interannual variability in algal biomass and primary production in the Mediterranean Sea, as derived from 4 years of SeaWiFS observations, Global Biogeochem. Cy., 18, GB1005, https://doi.org/10.1029/2003GB002034, 2004.

Brussaard, C. P. D.: Optimization of procedures for counting viruses by flow cytometry, Appl. Environ. Microb., 70, 1506-1513, 2004.

Cavalli, F., Viana, M., Yttri, K. E., Genberg, J., and Putaud, J.-P.: Toward a standardised thermal-optical protocol for measuring atmospheric organic and elemental carbon: the EUSAAR protocol, Atmos. Meas. Tech., 3, 79-89, https://doi.org/10.5194/amt-3-792010, 2010.

Ceburnis, D., Rinaldi, M., Ovadnevaite, J., Martucci, G., Giulianelli, L., and O'Dowd, C. D.: Marine submicron aerosol gradients, sources and sinks, Atmos. Chem. Phys., 16, 12425-12439, https://doi.org/10.5194/acp-16-12425-2016, 2016.

Christaki, U., Courties, C., Massana, R., Catala, P., Lebaron, P., Gasol, P., and Zubkov, M. V.: Optimized routine flow cytometric enumeration of heterotrophic flagellates using SYBR Green I, Limnol. Oceanogr.-Meth., 9, 329-339, 2011.

Clarke, A. D., Owens, S. R., and Zhou, J.: An ultrafine sea-salt flux from breaking waves: Implications for cloud condensation nuclei in the remote marine atmosphere, J. Geophys. Res., 111, D06202, https://doi.org/10.1029/2005JD006565, 2006.

Cochran, R. E., Jayarathne, T., Stone, E. A., and Grassian, V. H.: Selectivity across the interface: A test of surface activity in the composition of organic-enriched aerosols from bubble bursting, J. Phys. Chem. Lett., 7, 1692-1696, 2016.

Collins, D. B., Ault, A. P., Moffet, R. C., Ruppel, M. J., CuadraRodriguez, L. A., Guasco, T. L., Corrigan, C. E., Pedler, B. E., Azam, F., Aluwihare, L. I., Bertram, T. H., Roberts, G. C., Grassian, V. H., and Prather, K. A.: Impact of marine biogeochemistry on the chemical mixing state and cloud forming ability of nascent sea spray aerosol, J. Geophys. Res.-Atmos., 118, 85538565, 2013.

Dittmar, W.: Report on researches into the composition of ocean water collected by H.M.S. Challenger during the years 18731876, in: Voyage of H.M.S. Challenger, edited by: Murray, J., H.M. Stationery Office, London, 1884.

D'Ortenzio, F. and Ribera d'Alcalà, M.: On the trophic regimes of the Mediterranean Sea: a satellite analysis, Biogeosciences, 6, 139-148, https://doi.org/10.5194/bg-6-139-2009, 2009.

Facchini, M. C., Rinaldi, M., Decesari, S., Carbone, C., Finessi, E., Mircea, M., Fuzzi, S., Ceburnis, D., Flanagan, R., Nilsson, E. D., de Leeuw, G., Martino, M., Woeltjen, J., and O'Dowd, C. D.: Primary submicron marine aerosol dominated by insoluble organic colloids and aggregates, Geophys. Res. Lett., 35, L17814, https://doi.org/10.1029/2008GL034210, 2008.

Fuentes, E., Coe, H., Green, D., de Leeuw, G., and McFiggans, G.: Laboratory-generated primary marine aerosol via bubblebursting and atomization, Atmos. Meas. Tech., 3, 141-162, https://doi.org/10.5194/amt-3-141-2010, 2010a.

Fuentes, E., Coe, H., Green, D., de Leeuw, G., and McFiggans, G.: On the impacts of phytoplankton-derived organic matter on the properties of the primary marine aerosol Part 1: Source fluxes, Atmos. Chem. Phys., 10, 9295-9317, https://doi.org/10.5194/acp-10-9295-2010, 2010 b.

Fuentes, E., Coe, H., Green, D., and McFiggans, G.: On the impacts of phytoplankton-derived organic matter on the properties of the primary marine aerosol - Part 2: Composition, hygroscopicity and cloud condensation activity, Atmos. Chem. Phys., 11, 25852602, https://doi.org/10.5194/acp-11-2585-2011, 2011.

Gantt, B. and Meskhidze, N.: The physical and chemical characteristics of marine primary organic aerosol: a review, Atmos. Chem. Phys., 13, 3979-3996, https://doi.org/10.5194/acp13-3979-2013, 2013.

Grythe, H., Ström, J., Krejci, R., Quinn, P., and Stohl, A.: A review of sea-spray aerosol source functions using a large global set of sea salt aerosol concentration measurements, Atmos. Chem. Phys., 14, 1277-1297, https://doi.org/10.5194/acp-141277-2014, 2014.

Hultin, K., Krejci, R., Pinhassi, J., Gomez-Consarnau, L., Mårtensson, E. M., Hagström, A., and Nilsson, E. D.: Aerosol and bacterial emissions from Baltic Seawater, Atmos. Res., 99, 1-14, 2011.

Jaeglé, L., Quinn, P. K., Bates, T. S., Alexander, B., and Lin, J.-T.: Global distribution of sea salt aerosols: new constraints from in situ and remote sensing observations, Atmos. Chem. Phys., 11, 3137-3157, https://doi.org/10.5194/acp-11-3137-2011, 2011. 
Jaffrezo, J. L., Calas, N., and Boucher, M.: Carboxylic acids measurements with ionic chromatography, Atmos. Environ., 32, 2705-2708, 1998.

Keene, W. C., Maring, H., Maben, J. R., Kieber, D. J., Pszenny, A. A. P., Dahl, E. E., Izaguirre, M. A., Davis, A. J., Long, M. S., Zhou, X., Smoydzin, L., and Sander, R.: Chemical and physical characteristics of nascent aerosols produced by bursting bubbles at a model air-sea interface, J. Geophys. Res., 112, D21202, https://doi.org/10.1029/2007JD008464, 2007.

King, S. M., Butcher, A. C., Rosenoern, T., Coz, E., Lieke, K. I., de Leeuw, G., Nilsson, E. D., and Bilde, M.: Investigating Primary Marine Aerosol Properties: CCN Activity of Sea Salt and Mixed Inorganic-Organic Particles, Environ. Sci. Technol., 46, 1040510412, https://doi.org/10.1021/es300574, 2012.

Köhler, $\mathrm{H}$ : The nucleus in and the growth of hygroscopic droplets, Trans. Faraday Soc., 32, 1152-1161, https://doi.org/10.1039/TF9363201152, 1936.

Koulouri, E., Saarikoski, S., Theodosi, C., Markaki, Z., Gerasopoulos, E., Kouvarakis, G., Mäkelä, T., Hillamo, R., and Mihalopoulos, N.: Chemical composition and sources of fine and coarse aerosol particles in the Eastern Mediterranean, Atmos. Environ., 42, 6542-6550, https://doi.org/10.1016/j.atmosenv.2008.04.010, 2008.

Lebaron, P., Servais, P., Agogue, H., Courties, C., and Joux, F.: Does the high nucleic acid content of individual bacterial cells allow us to discriminate between active cells and inactive cells in aquatic system?, Appl. Environ. Microb., 67, 1775-1782, 2001.

Long, M. S., Keene, W. C., Kieber, D. J., Frossard, A. A., Russell, L. M., Maben, J. R., Kinsey, J. D., Quinn, P. K., and Bates, T. S.: Light-enhanced primary marine aerosol production from biologically productive seawater, Geophys. Res. Lett., 41, 2661-2670, https://doi.org/10.1002/2014GL059436, 2014.

Mårtensson, E. M., Nilsson, E. D., de Leeuw, G., Cohen, L. H., and Hansson, H.-C.: Laboratory simulations and parameterization of the primary marine aerosol production, J. Geophys. Res., 108, 4297, https://doi.org/10.1029/2002JD002263, 2003.

MERMEX group: Marine ecosystems responses to climatic and anthropogenic forcings in the Mediterranean, Prog. Oceanogr., 91, 97-166, 2011.

Modini, R. L., Harris, B., and Ristovski, Z. D.: The organic fraction of bubble-generated, accumulation mode Sea Spray Aerosol (SSA), Atmos. Chem. Phys., 10, 2867-2877, https://doi.org/10.5194/acp-10-2867-2010, 2010.

Moore, M. J. K., Furutani, H., Roberts, G. C., Moffet, R. C., Gilles, M. K., Palenik, B., and Prather, K. A.: Effect of organic compounds on cloud condensation nuclei $(\mathrm{CCN})$ activity of sea spray aerosol produced by bubble bursting, Atmos. Environ., 45, 74627469, 2011.

Norris, S. J., Brooks, I. M., and Salisbury, D. J.: A wave roughness Reynolds number parameterization of the sea spray source flux, Geophys. Res. Lett., 40, 4415-4419, https://doi.org/10.1002/grl.50795, 2013.

O’Dowd, C. D., Facchini, M. C., Cavalli, F., Ceburnis, D., Mircea, M., Decesari, S., Fuzzi, S., Yoon, Y. J., and Putaud, J.-P.: Biogenically driven organic contribution to marine aerosol, Nature, 431, 676-680, 2004.

O’Dowd, C. D., Langmann, B., Varghese, S., Scannell, C., Ceburnis, D., and Facchini, M. C.: A combined organic-inorganic sea-spray source function, Geophys. Res. Lett., 35, L01801, https://doi.org/10.1029/2007GL030331, 2008.

O’Dowd, C. D., Ceburnis, D., Ovadnevaite, J., Bialek, J., Stengel, D. B., Zacharias, M., Nitschke, U., Connan, S., Rinaldi, M., Fuzzi, S., Decesari, S., Facchini, M. C., Marullo, S., Santoleri, R., Dell'Anno, A., Corinaldesi, C., Tangherlini, M., and Danovaro, R.: Connecting marine productivity to sea-spray via nanoscale biological processes: Phytoplankton Dance or Death Disco?, Scientific Reports, 5, 14883, https://doi.org/10.1038/srep14883, 2015.

Ovadnevaite, J., Ceburnis, D., Martucci, G., Bialek, J., Monahan, C., Rinaldi, M., Facchini, M. C., Berresheim, H., Worsnop, D. R., and O'Dowd, C.: Primary marine organic aerosol: A dichotomy of low hygroscopicity and high CCN activity, Geophys. Res. Lett., 38, L21806, https://doi.org/10.1029/2011GL048869, 2011.

Ovadnevaite, J., Manders, A., de Leeuw, G., Ceburnis, D., Monahan, C., Partanen, A.-I., Korhonen, H., and O'Dowd, C. D.: A sea spray aerosol flux parameterization encapsulating wave state, Atmos. Chem. Phys., 14, 1837-1852, https://doi.org/10.5194/acp14-1837-2014, 2014.

Partanen, A.-I., Dunne, E. M., Bergman, T., Laakso, A., Kokkola, H., Ovadnevaite, J., Sogacheva, L., Baisnée, D., Sciare, J., Manders, A., O’Dowd, C., de Leeuw, G., and Korhonen, H.: Global modelling of direct and indirect effects of sea spray aerosol using a source function encapsulating wave state, Atmos. Chem. Phys., 14, 11731-11752, https://doi.org/10.5194/acp-14-117312014, 2014.

Passow, U. and Alldredge, A. L.: Distribution, size and bacterial colonization of transparent exopolymer particles (TEP) in the ocean, Mar. Ecol.-Prog. Ser., 113, 185-198, 1994.

Petters, M. D. and Kreidenweis, S. M.: A single parameter representation of hygroscopic growth and cloud condensation nucleus activity, Atmos. Chem. Phys., 7, 1961-1971, https://doi.org/10.5194/acp-7-1961-2007, 2007.

Pey, J., Alastuey, A., and Querol, X.: $\mathrm{PM}_{10}$ and $\mathrm{PM}_{2.5}$ sources at an insular location in the western Mediterranean by using source apportionment techniques, Sci. Total Environ., 456-457, 267-277, 2013.

Pilson, M. E. Q.: An Introduction to the Chemistry of the Sea, Prentice-Hall Inc, Upper Saddle River, N.J., 431 pp., 1998.

Prather, K. A., Bertram, T. H., Grassian, V. H., Deane, G. B., Stokes, M. D., Demott, P. J., Aluwihare, L. I., Palenik, B. P., Azam, F., Seinfeld, J. H., Moffet, R. C., Molina, M. J., Cappa, C. D., Geiger, F. M., Roberts, G. C., Russell, L. M., Ault, A. P., Baltrusaitis, J., Collins, D. B., Corrigan, C. E., Cuadra-Rodriguez, L. A., Ebben, C. J., Forestieri, S. D., Guasco, T. L., Hersey, S. P., Kim, M. J., Lambert, W. F., Modini, R. L., Mui, W., Pedler, B. E., Ruppel, M. J., Ryder, O. S., Schoepp, N. G., Sullivan, R. C., and Zhao, D.: Bringing the ocean into the laboratory to probe the chemical complexity of sea spray aerosol, P. Natl. Acad. Sci. USA, 110, 7550-7555, 2013.

Pringle, K. J., Tost, H., Pozzer, A., Pöschl, U., and Lelieveld, J.: Global distribution of the effective aerosol hygroscopicity parameter for CCN activation, Atmos. Chem. Phys., 10, 52415255, https://doi.org/10.5194/acp-10-5241-2010, 2010.

Raimbault, P., Rodier, M., and Taupier-Letage, I.: Size fractionation of phytoplankton in the Ligurian Sea and the Algerian Basin (Mediterranean): size fraction versus total concentrations, Marine Microbial Food Webs, 3, 1-7, 1988. 
Ramzy, B. N., Tadros, H. R. Z., Abou Taleb, A. E. A., and Moawad, M. N.: Chemistry of the Egyptian Mediterranean coastal waters, Egyptian Journal of Aquatic Research, 41, 1-10, 2015.

Rinaldi, M., Fuzzi, S., Decesari, S., Marullo, S., Santoleri, R., Provenzale, A., von Hardenberg, J., Ceburnis, D., Vaishya, A., O'Dowd, C. D., and Facchini, M. C.: Is chlorophyll-a the best surrogate for organic matter enrichment in submicron primary marine aerosol?, J. Geophys. Res.-Atmos., 118, 4964-4973, 2013.

Roberts, G. C. and Nenes, A.: A Continuous-Flow Streamwise Thermal-Gradient CCN Chamber for Atmospheric Measurements, Aerosol Sci. Technol., 39, 206-221, 2005.

Rose, D., Gunthe, S. S., Mikhailov, E., Frank, G. P., Dusek, U., Andreae, M. O., and Pöschl, U.: Calibration and measurement uncertainties of a continuous-flow cloud condensation nuclei counter (DMT-CCNC): CCN activation of ammonium sulfate and sodium chloride aerosol particles in theory and experiment, Atmos. Chem. Phys., 8, 1153-1179, https://doi.org/10.5194/acp8-1153-2008, 2008.

Saad, M. A. and Abdel-Moati, A. R.: Major ions in the Damietta branch of the River Nile, Egypt. Acta hydrochimica et hydrobiologica, 2, 153-158, 1991.

Saad, M. A. H. and Hussain, N. A.: Preliminary studies on sodium, magnesium, calcium and Potassium in the north-west Arab Gulf, Arab Gulf, 9, 19-27, 1978.

Salter, M. E., Nilsson, E. D., Butcher, A., and Bilde, M.: On the seawater temperature dependence of the sea spray aerosol generated by a continuous plunging jet, J. Geophys. Res., 2014.

Salter, M. E., Zieger, P., Acosta Navarro, J. C., Grythe, H., Kirkevåg, A., Rosati, B., Riipinen, I., and Nilsson, E. D.: An empirically derived inorganic sea spray source function incorporating sea surface temperature, Atmos. Chem. Phys., 15, 1104711066, https://doi.org/10.5194/acp-15-11047-2015, 2015.

Salter, M. E., Hamacher-Barth, E., Leck, C., Werner, J., Johnson, C. M., Riipinen, I., Nilsson, E. D., and Zieger, P.: Calcium enrichment in sea spray aerosol particles, Geophys. Res. Lett., 119, 9052-9072, https://doi.org/10.1002/2013JD021376, 2016.

Schwier, A. N., Rose, C., Asmi, E., Ebling, A. M., Landing, W. M., Marro, S., Pedrotti, M.-L., Sallon, A., Iuculano, F., Agusti, S., Tsiola, A., Pitta, P., Louis, J., Guieu, C., Gazeau, F., and Sellegri, K.: Primary marine aerosol emissions from the Mediterranean Sea during pre-bloom and oligotrophic conditions: correlations to seawater chlorophyll a from a mesocosm study, Atmos. Chem. Phys., 15, 7961-7976, https://doi.org/10.5194/acp15-7961-2015, 2015.

Seinfeld, J. H. and Pandis, S. N.: Atmospheric Chemistry \& Physics: From Air Pollution to Climate Change, John Wiley \& Sons, New York, 1998.

Sellegri, K., O’Dowd, C. D., Yoon, Y. J., Jennings, S. G., and de Leeuw, G.: Surfactants and submicron sea spray generation, J. Geophys. Res., 111, D22215, https://doi.org/10.1029/2005JD006658, 2006.

Sempéré, R., Para, J., Tedetti, M., Charrière, B., and Mallet, M.: Variability of Solar Radiation and CDOM in Surface Coastal Waters of the Northwestern Mediterranean Sea, Photochem. Photobiol., 91, 851-861, https://doi.org/10.1111/php.12434, 2015.
Siokou-Frangou, I., Christaki, U., Mazzocchi, M. G., Montresor, M., Ribera d'Alcalá, M., Vaqué, D., and Zingone, A.: Plankton in the open Mediterranean Sea: a review, Biogeosciences, 7, 15431586, https://doi.org/10.5194/bg-7-1543-2010, 2010.

Sohrin, R. and Sempéré, R.: Seasonal variation in total organic carbon in the northeast Atlantic in 2000-2001, J. Geophys. Res., 110, C10S90, https://doi.org/10.1029/2004JC002731, 2005.

Takahashi, T., Broecker, W. S., and Langer, S.: Redfield ratio based on chemical data from isopyncal surfaces, J. Geophys. Res., 90, 6907-6924, 1985.

Turpin, B. and Lim, H.-J.: Species Contributions to $\mathrm{PM}_{2.5}$ Mass Concentrations: Revisiting Common Assumptions for Estimating Organic Mass, Aerosol Sci. Technol., 35, 602-610, 2001.

Treguer, P. and LeCorre, P.: Manuel d'analyse des sels nutritifs dans l'eau de mer (Utilisation de l'autoAnalyseur II), 2nd Edn., Laboratoire d'Océanographie chimique, Université de Bretagne Occidentale, Brest, 110 pp., 1975.

Vidussi, F., Mostajir, B., Fouilland, E., Le Floc'h, E., Nouguier, J., Roques, C., Got, P., Thibault-Botha, D., Bouvier, T., and Troussellier, M.: Effects of experimental warming and increased ultraviolet $\mathrm{B}$ radiation on the Mediterranean plankton food web, Limnol. Oceanogr., 56, 206-218, 2011.

Vignati, E., Facchini, M. C., Rinaldi, M., Scannell, C., Ceburnis, D., Sciare, J., Kanakidou, M., Myriokefalitakis, S., Dentener, F., and O'Dowd, C. D.: Global scale emission and distribution of seaspray aerosol: Sea-salt and organic enrichment, Atmos. Environ., 44, 670-677, 2010.

Westervelt, D. M., Moore, R. H., Nenes, A., and Adams, P. J.: Effect of primary organic sea spray emissions on cloud condensation nuclei concentrations, Atmos. Chem. Phys., 12, 89-101, https://doi.org/10.5194/acp-12-89-2012, 2012.

Wright, S. W., Jeffrey, S. W., Mantoura, R. F., Llewellyn, C. A., Bjornland, T., Repeta, D., and Welschmeyer, N.: Improved HPLC method for the analysis of chlorophylls and carotenoids from marine phytoplankton, Mar. Ecol.-Prog. Ser., 77, 183-196, 1991.

Young, K. C. and Warren, A. J.: A Reexamination of the dérivation of the equilibrium supersaturation curve for soluble particles, J. Atmos. Sci., 49, 1138-1143, 1992.

Zábori, J., Krejci, R., Ekman, A. M. L., Mårtensson, E. M., Ström, J., de Leeuw, G., and Nilsson, E. D.: Wintertime Arctic Ocean sea water properties and primary marine aerosol concentrations, Atmos. Chem. Phys., 12, 10405-10421, https://doi.org/10.5194/acp-12-10405-2012, 2012a.

Zábori, J., Matisans, M., Krejci, R., Nilsson, E. D., and Ström, J.: Artificial primary marine aerosol production: a laboratory study with varying water temperature, salinity, and succinic acid concentration, Atmos. Chem. Phys., 12, 10709-10724, https://doi.org/10.5194/acp-12-10709-2012, 2012 b. 